\title{
فاعلية برنامج للتدريبات الفنية الإجبارية على تطوير أداء بعض كان الجوانب البدنية والخططية لناشئي كرة القدم

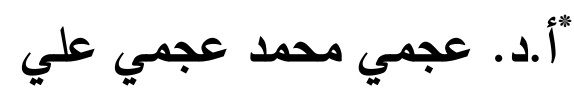

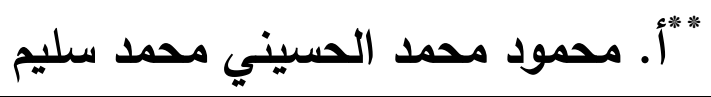

المقدمة ومشكلة البحث:

لقد أصبح التقدم العلمي السمة المميزة للعصر الحالي لما يساهم به في إيجاد الكثير من الحلول

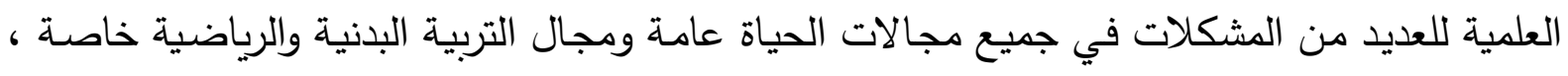

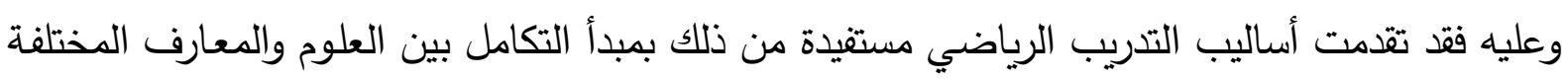
والتي تهدف إلى الوصول باللاعب إلي المستوى الذي يمكنه من تحقيق أفضل الإنجازات الرياضية في لفي

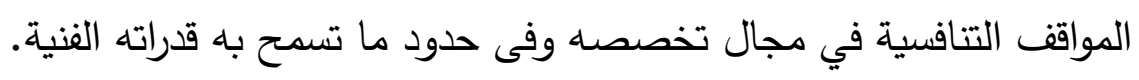

ويعد التدريب الرياضي احد أهم أثكال الممارسة الرياضية المنظمة وهي وسيلة هامة من وسائل

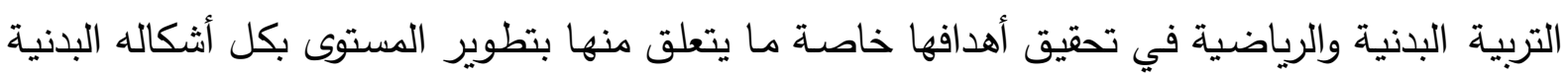

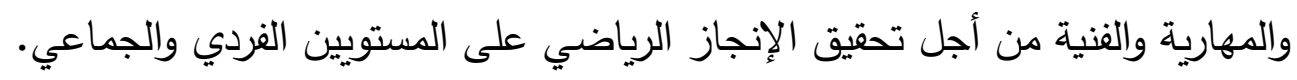

ويتقق هذا مع ما يثير إليه عمرو أبو المجد ( •99 (9م) بأن التخطيط الحديث في تدريب كرة

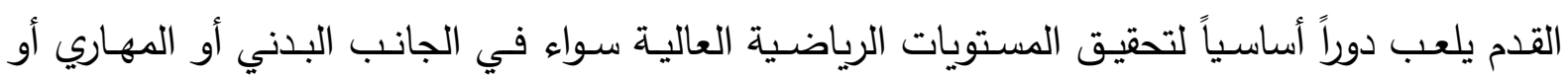

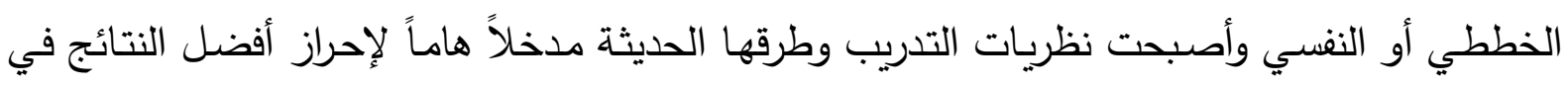

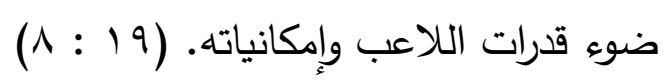

ويذكر حنفي محمود مختار ( • 199 م) أن عملية تخطيط التدريب فى كرة القدم لها متطلبات

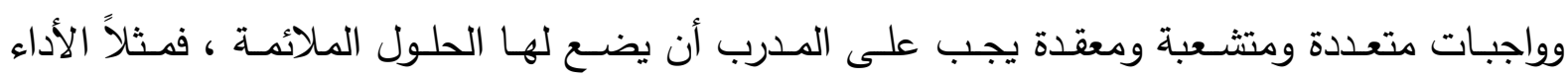

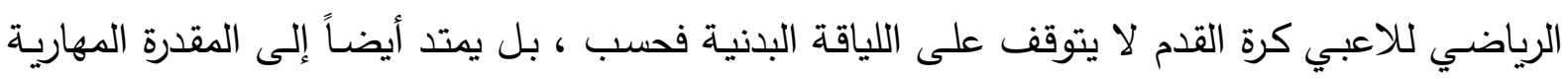

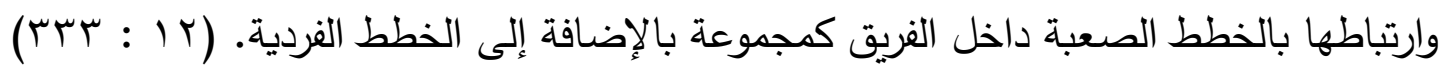

• أستاذ تدريب كرة القدم ورئيس قسم نظريات وتطبيقات الرياضات الجماعية، بكلية التربية الرياضية للبنين، جامعة الزقازيق. " " أخصائى رياضى بالإدارة العامة لرعاية الطلاب - جامعة الزقازيق. 
وانه بدون تخطيط رياضي لا يمكن تحديد المستوى الذي يجب أن يصل إليه اللاعب أو الفريق خلال فترة زمنية محددة أو من خلال فترة المنافسات ، حيث يتوقف تقدم وتطور الأداء في أي نشاط من الأنشطة الرياضية على المستوى العمل العلمي المخطط ، فالتخطيط يعنى التتبؤ والمدرب الذي يخطط لموسم رياضي يضع أهدافاً أمامه يعمل على تحقيقها ومن هنا يمكن أن يتتبأ بالمستوى الذي سيصل إليه لاعبوه. (1:11)

ويشير لطفي محمد كمـال (ب99 ا9م) إلى أن التدريب الحديث فى كرة القدم أصبح يعتمد كليا على وضع برنامج زمني علمي مدروس يشمل الإعداد البدنى والمهارى والخططي والنفسي والعقلي حتى

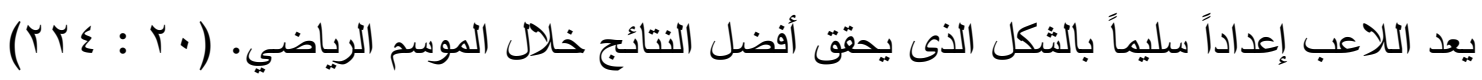

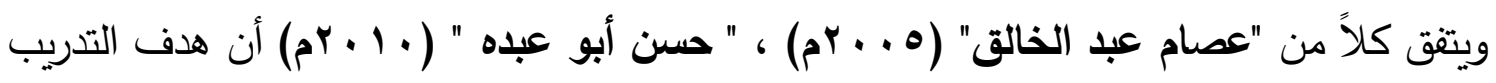
فى كرة القدم هو الإعداد المتكامل للاعب بدنياً ومهارياً وخططياً وفكرياً ونفسياً لتحقيق أعلى مستوى من الأداء المتكامل ويعتبر العمل الخططى فى كرة القدم الحديثة هو ذلك العمل التكتيكى الذى يحتوى عناصر التكتيك الفردى والجماعى بهدف تنفيذ التحركات الهادفة والاقتصادية التى تقوم بها مجموعة من

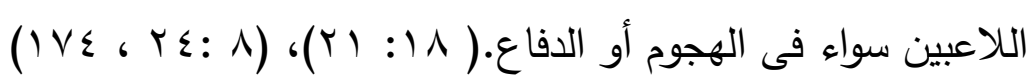

ويذكر " عصام عبد الخالق" (0 . . r م) أن النواحى البدنية والمهارية والنفسية قد حظت باهتمام الباحثين والمدربين أما الناحية " الخططية التكتيكية" فمازالت لم تتل حظها بعد من اهتمام الباحثين والمدربين ومازال هناك الكثير من الجوانب الخططية التى يجب أن يضعها المدربين نصب أعينهم أثناء

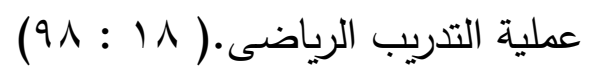

وطبيعة المباراة تمر بمتغيرات كثيرة من آن لأخر ويستوجب ذلك إعداد وتهيئة اللاعبين لمواجهه تلك المتغيرات من خلال الارتقاء بمستوى الأداء المهاري طبقاً لشروط المباراة وظروف الموقف. ويشير إبراهيم مجدي أحمد صالح (9^ه ام) انه من الملاحظ أن مستوى الأداء في كرة القدم ارتقع بصورة تتمشى مع تطور طرق اللعب وتتوع الخطط الدفاعية والهجومية ، الأمر الذي يتطلب تميز لاعب كرة القدم بأعلى مستوى من الأداء خلال المباريات ، وعليه فإنه يجب إعداد اللاعب إعداداً فنياً

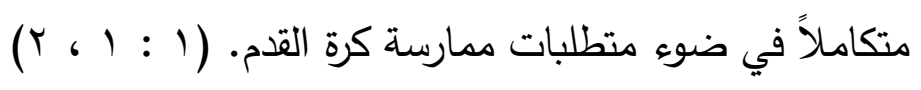

Donskoi \& ويشير جمال محمد علاء الدين (199) (م) نقلاً عن دونسكوى و زاتسيورسكى Zatsiorsky 
كلية وليست فقط مجرد مجموعة الأجزاء المكونة لها ، حيث تترابط أجزائها من خلال ارتباطات عديدة ومتبادلة والتي تكسبها خواص جديدة لم تكن متضمنة أصلاً في خواص إجرائها. ( ا : ؟ )

ويضيف منير جرجس إبراهيم (•99 (9) أن التدريب على المهارات الحركية يعتبر من أهم أركان

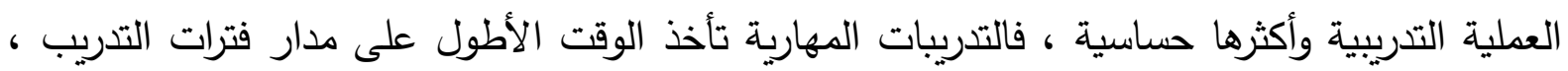

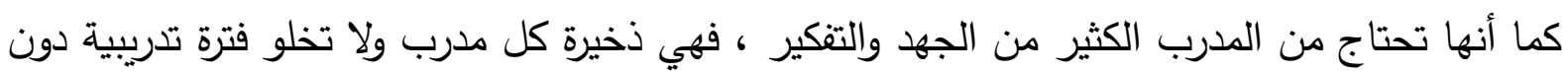

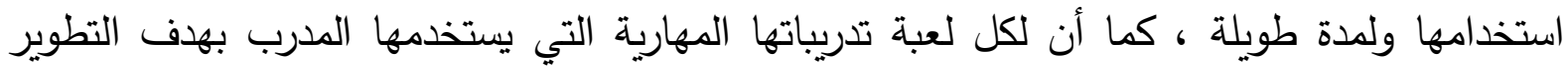

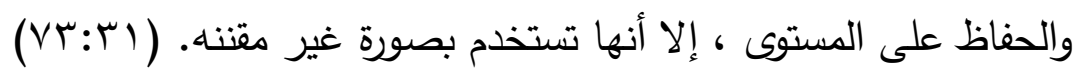

ويؤكد خالد سعيد النبي إبراهيم (99V (م) على أن تدريب الناشئ على أشكال متتوعة من الأداء

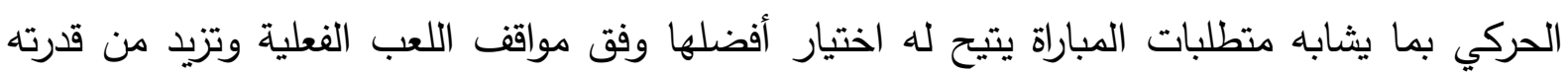

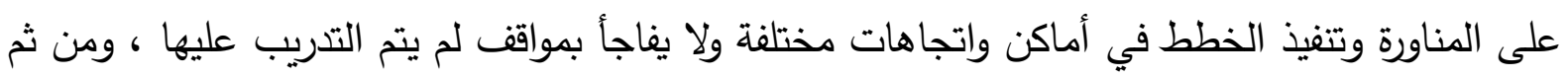

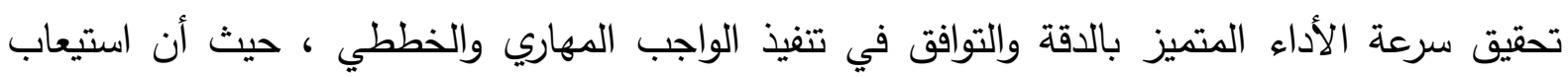

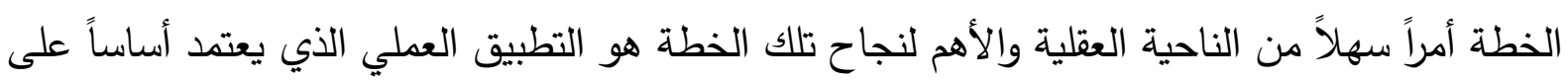

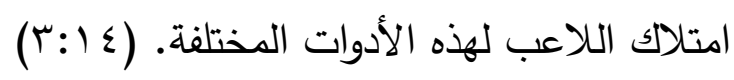

ويتقق هذا مع العديد من الدراسات التى تناولت تأثير الجوانب الفنية للاعبي كرة القدم على نتائج

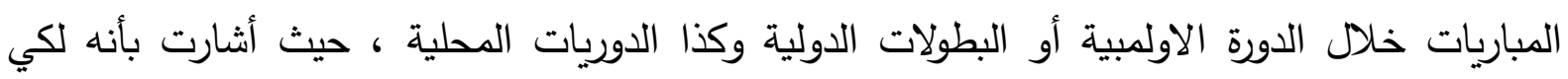

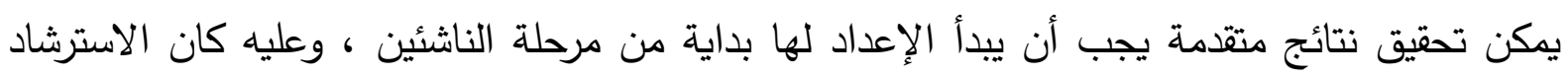

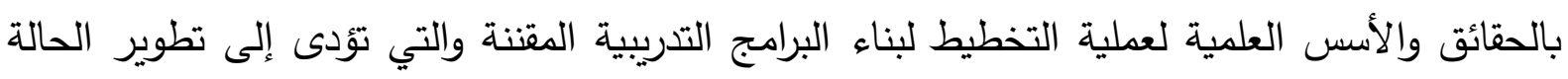
التدريبية للناشئ وتجعله لائقاً من الناحية الفنية.

ويرى مفتى إبراهيم (،99 ا9م) انه كلما ارتفع مستوى أداء اللاعبين للمهارات الأساسية ، أمكن الارتقاء بالمستوى الخططي لهم نظراً لأن اللاعبين في هذه الحالة سيؤدون المهارات بصورة آلية مما يتيح

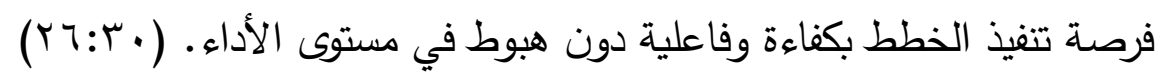

ولكي يحقق لاعب كرة القدم أعلى مستوى من الأداء الفني في الدفاع والهجوم أثناء المباراة يجب أن يعد إعداداً متكاملاً مبنياً على أسس علمية تتاسب طبيعة اللعبة وزمن المباراة ومساحة الملعب والواجبات الدفاعية والهجومية المطلوبة من كل لاعب لإحراز أفضل النتائج. 


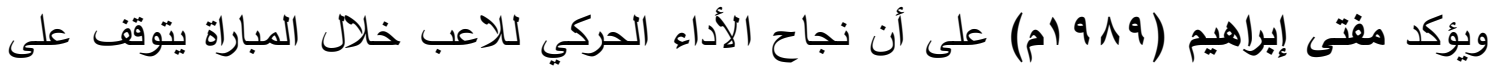

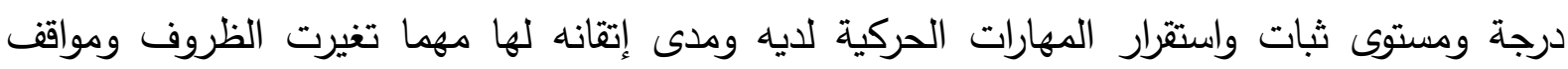

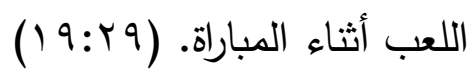

ويرى كل من محمد حسن علاوي (7 9191م) ، حنفي محمود مختار (،99 ام) أن عملية الإعداد

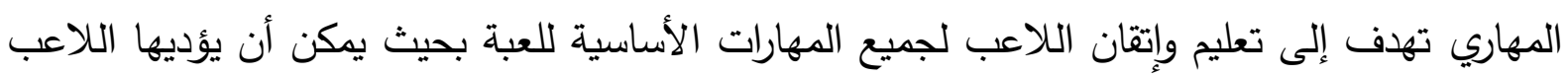

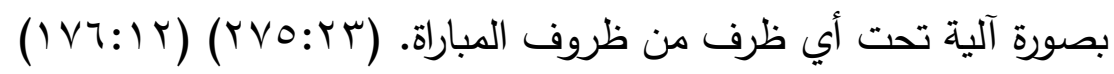

وتعتبر المهارات الأساسية أحد الجوانب الفنية المميزة لنوع النشاط الرياضي الممارس والعمود الفقري للعملية التدريبية وخاصة مرحلة إعداد الناشئين ، حيث يتلقى اللاعب الخطوط العريضة للأداء

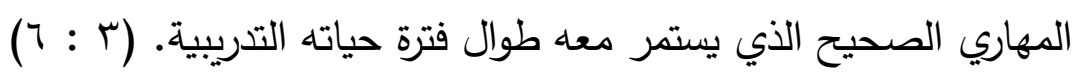

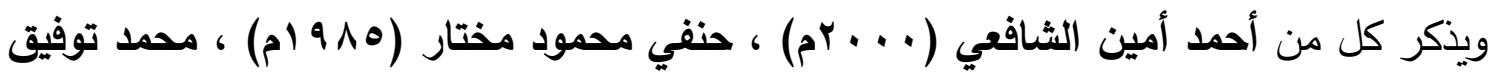

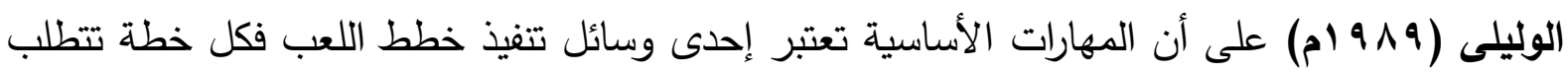

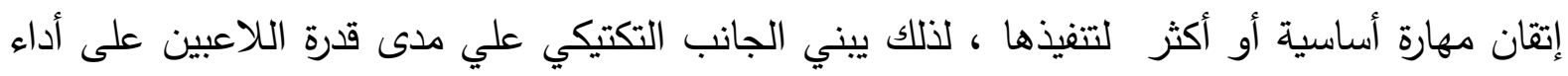

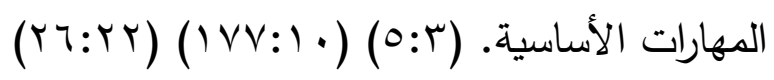

وأثار كل من حنفي محمود مختار ومفتى إبراهيم (9 9 ا9م) إلى أن كل مهارة أساسية في كرة

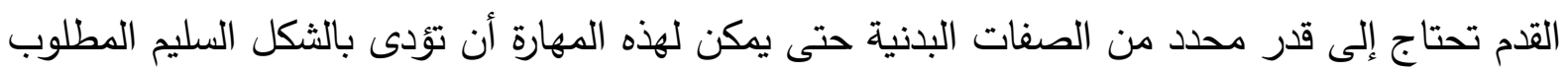

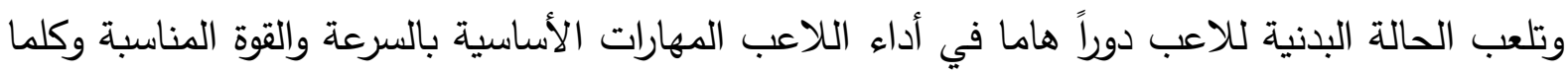

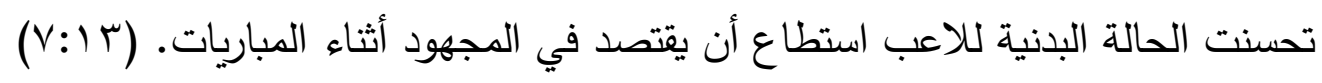

ويرى كل من حنفي محمود مختار (·191م) ، محمود أبو العينين ومفتى إبراهيم (919 ام) أن

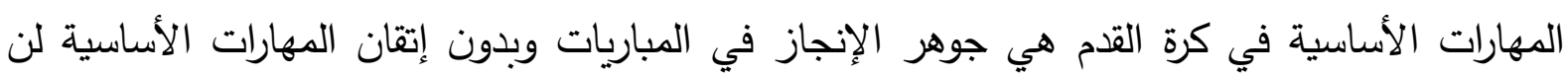

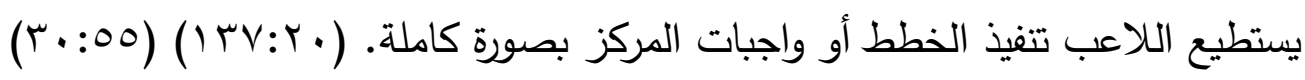

ويضيف عجمي محمد عجمي (1990 م) نقلاً حنفي محمود مختار (ب9 199م) عن أن واجبات

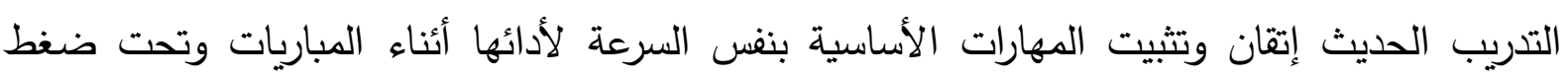
مدافع إيجابي حتى يتعود اللاعبون سرعة الأداء والحركة تحت ضغط ظروف اللعب المختلفة. ( V V)

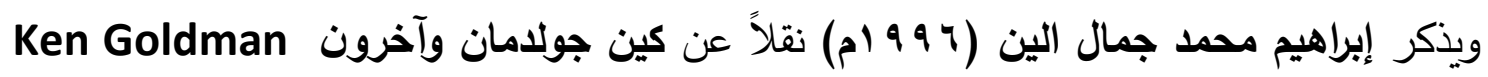
\& others 
هذه المرحلة يجب على الناشئ أن يتعلم معظم المهارات الأساسية التي تساعد على الأداء في المباراة ،

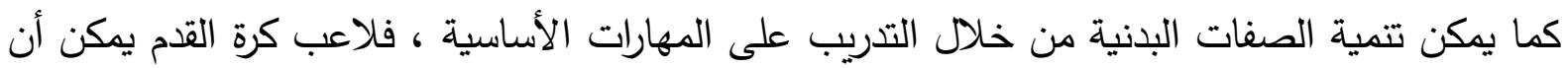

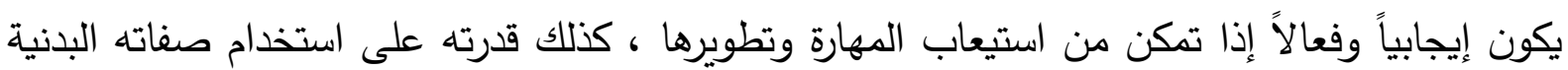

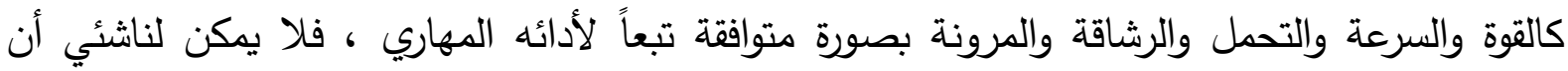
يكون ذا قدرة على أداء المهارات فى كرة القدم إذا لم يستطيع تقدير القوة والسرعة اللازمة لأدائها. $(\varepsilon: r)$

والظاهرة التي تميز لاعبي كرة القدم الممتازين الآن هي مقدرتهم الفائقة على الأداء المهاري الدقيق

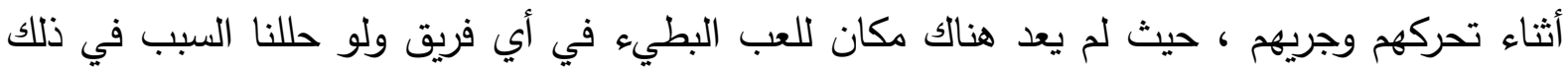

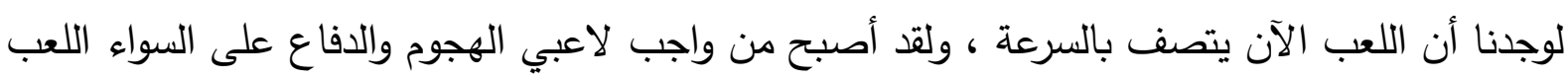

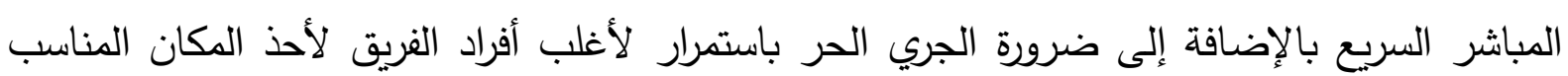

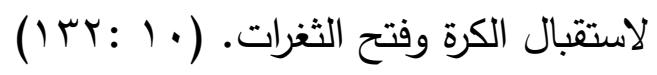

وهناك اعتبارات خططية يجب على اللاعب مراعاتها عند أداء المهارات منها التعديل في التكوين

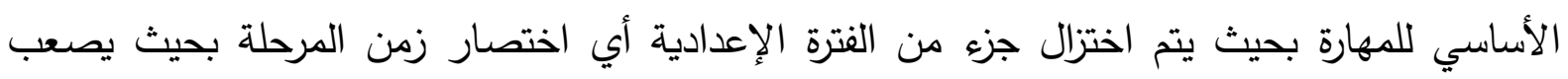

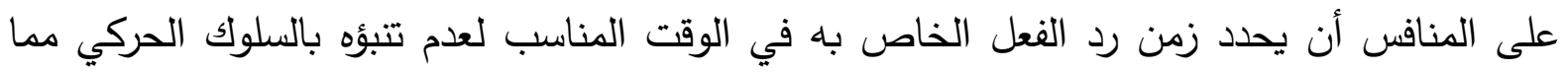

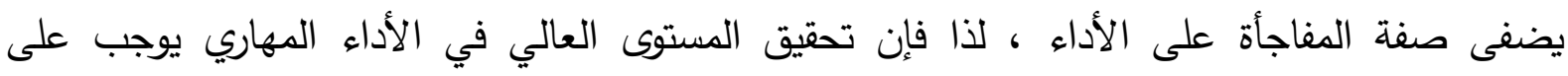

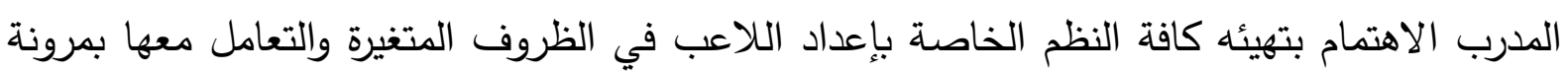

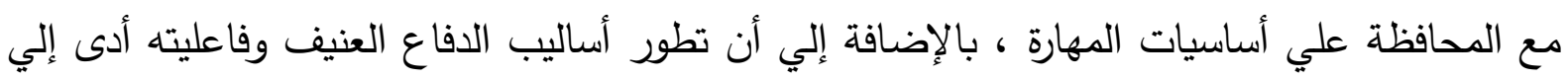

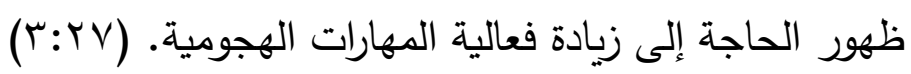

لذا فمن الأمور الهامة استخدام الأشكال التدريبية التي تكون قريبة من شكل المنافسة في كرة القدم على أن يكون اكتسابها مبكراً قدر الإمكان حتى يمكن استغلال الوقت الكافي في التدريب على هذه الأه

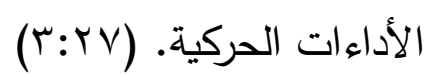

والتدريبات الفنية الإجبارية هي احد طرق التدريب على المهارات الأساسية حيث أنها توضح

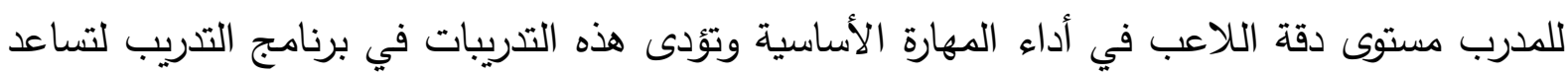

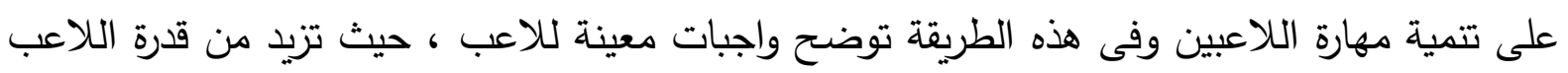
على التصرف في كافة مواقف اللعب المختلفة من حيث التعامل مع الكرة باستخدام مهارة واحدة (مهارة

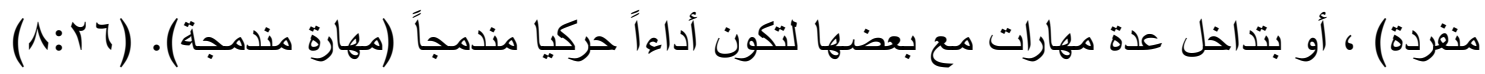


ومن خلال ما تقدم فقد لاحظ الباحثان بمدى أهمية الإعداد الفني والمتمثل في الجانب المهاري للاعب من حيث تطوير و إتقان المهارات الأساسية وذلك باستخدام برنامج للتدربات الفنية الإجبارية وتأثيره على تنفيذ الجانب البدني و الخططي بكفاءة وفاعلية وبالتالي حسم نتائج المباريات لصالح الفريق ذو المستوى العالي من إتقان المهارات الأساسية دون هبوط في مستوى الأداء.

لذا تتضح أهمية البحث والحاجة إليه في توجيه وترشيد عملية التدريب لندرة البحوث في استخدام التدريبات الفنية الاجبارية في تطوير أداء المهارات الفردية والمندمجة - المركبة وفاعليتها علي اداء بعض الجوانب البدنية والخططية لناشئي كرة القدم ، فضلاً عن أهمية تحديد كم وشكل الأداءات الحركية المركبة التي يمتلكها اللاعبون وارتباطها بالوظيفة التخصصية (المراكز - خطط اللعب) في تقييم مستوى إتقان الجوانب الخططية في كرة القدم ، ولذلك يرى الباحثان أهمية إجراء هذه الدراسة بهدف التوصل إلى أسلوب أفضل للتدريب على الأداءات الحركية المركبة فى كرة القدم من خلال مواقف اللعب المختلفة، ليتثى للاعبين القيام بأداء واجباتهم الخططية بكفاءة وبشكل مؤثر وتحقيق التفوق والإنجاز فى إطار ما تكفله لوائح وقانون كرة القدم وتتجلى فكرة البحث فى معرفة فاعلية برنامج للتدريبات الفنية الإجبارية على تطوير أداء بعض الجوانب البدنية والخططية لناشئي كرة القدم.

أهدافـ البصث:

\section{يهرف هذا البحث الى تصميم برنامج تدريبى مقترح للتدرببات الفنية الاجبارية وذلك للتعرف على:}

ا ـ تأثير البرنامج التدريبى المقترح على تطوير اداء بعض الجوانب البدنية لدى ناشئي كرة القدم. ץ. تأثير البرنامج التدريبى المقترح على تطوير اداء بعض الجوانب الخططية لدى ناشئي كرة القدم. r. التعرف علي نسب التحسن في تطوير اداء الجوانب البدنية والخططية لدي ناشئي كرة القدم.

\section{فروض البحث :}

ا-توجد فروق دالة إحصائيا بين القياس القبلي والقياس البعدي للمجموعة التجريبية لصالح القياس البعدي في تطوير أداء بعض الجوانب البدنية لناشئي كرة القدم تحت 1 ا سنة.

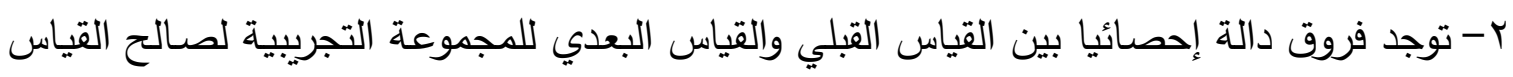
البعدي في تطوير أداء بعض الجوانب الخططية لناشئي كرة القدم تحت 1 ا سنة. r-توجد فروق في نسبال تحسن بين القياس القبلي والقياس البعدي للمجموعة التجريبية لصـالح القياس البعدي في تطوير اداء بعض الجوانب البدنية والخططيـة لناشئي كرة القدم تحت 1 1 


\section{المصطلحات المستخدمة في البحث :}

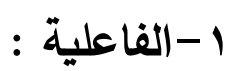

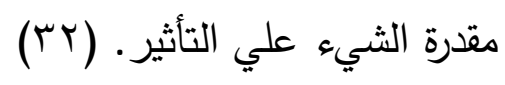

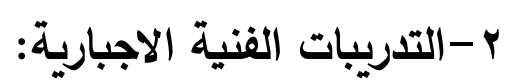

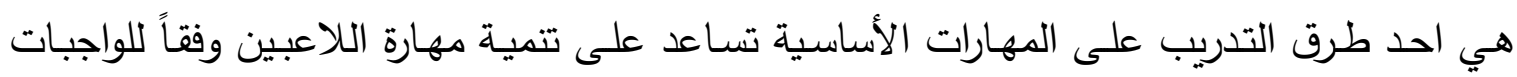
المخصصة للاعب والتى تتمثل وتتزكز على اداء المهارة وفقاً للخطوات الفنية للاداء. (ج؟ : . ( )

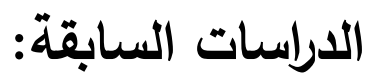

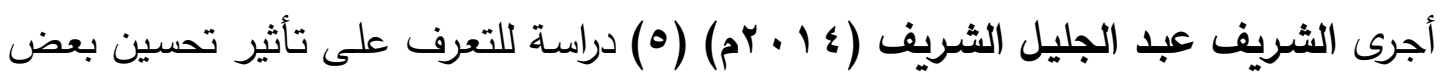

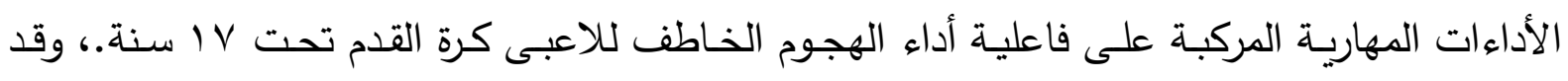

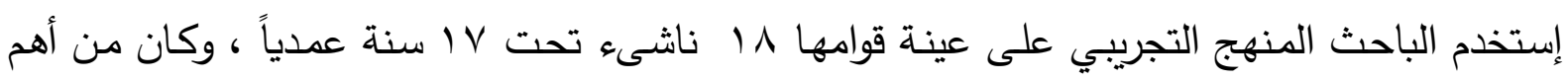
النتائج ان البرنامج التدريبى اثر على تحسين الأداءات المهارية المركبة وسرعتها وتنفيذها بثكل مؤثر . وقام طلال السيد حسن عبدالجواد . (11 + بم) (14) بدراسة إستهدفت التعرف على تأثير فاعلية

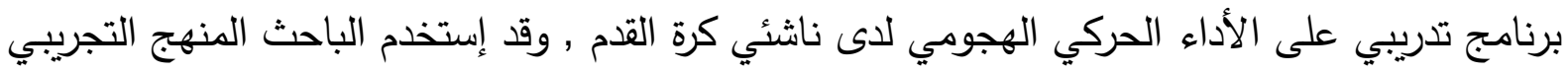

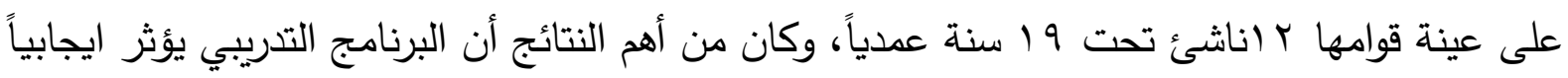

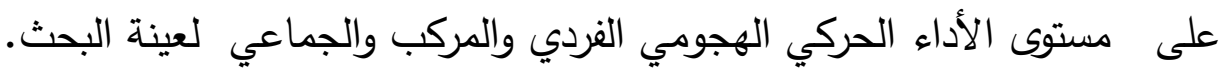

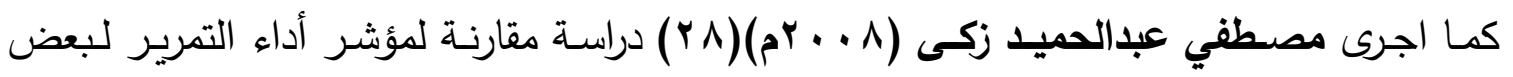

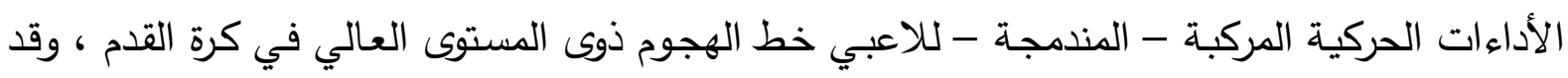

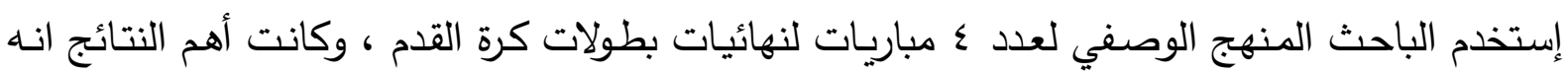

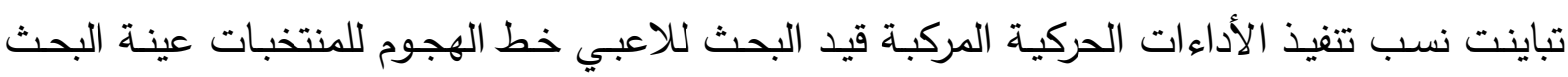

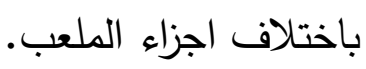

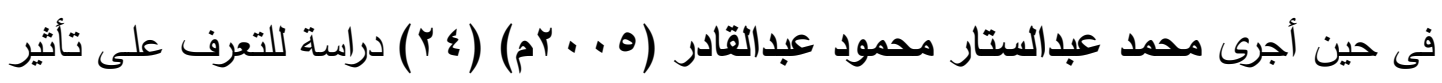

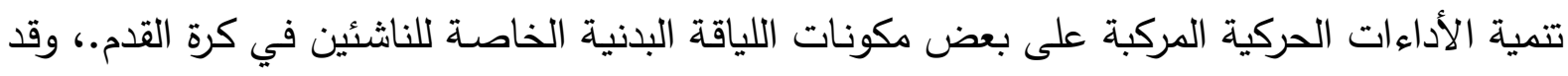

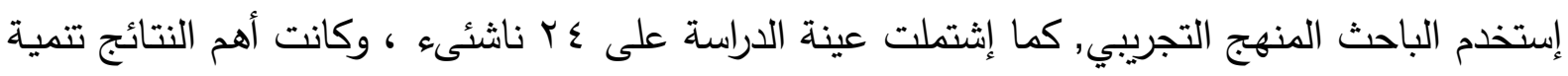

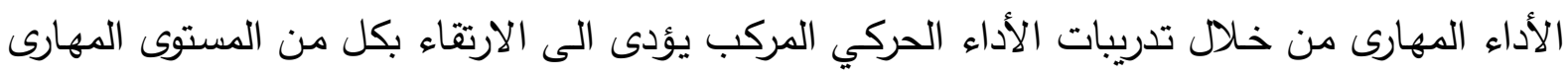

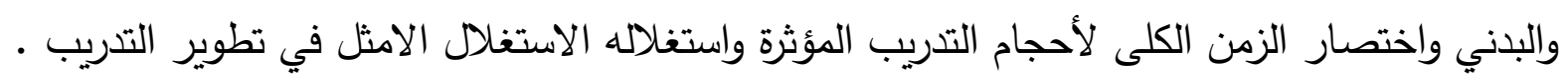


وقام محمد ابراهيم سلطان (ع . . rم) (Y Y) بدراسة نسبة مساهمة المهارات الاساسية المركبة "المندمجة" على اداء بعض المبادئ الخططية الهجومية للاعبي كرة القدم ., وقد إستخدم الباحث المنهج

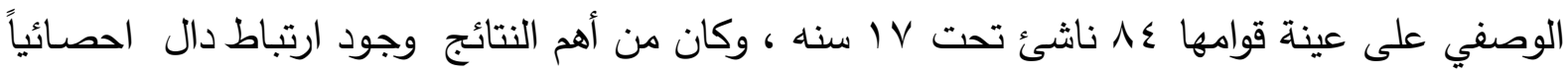
بين الأداء الناجح لمجموعة المبادئ الخططية الهجومية قيد الدراسـة وكل من مهارة الاستلام ثم الجري بالكرة ثم التمرير والاستلام ثم المراوغة ثم التمرير في عنصر الزمن.

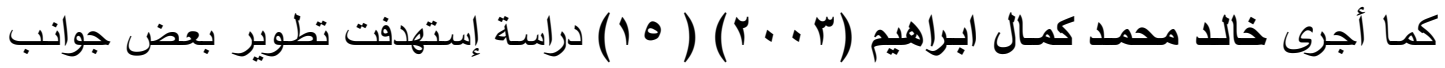
الأداء المهارى وعلاقته ببعض الجمل الخططية للاعبي كرة القدم للناشئين تحت 9 التسنة خـلال فترة الاعداد، وقد استخدم الباحث المنهج التجريبي , وقد قام الباحث باختيار عينة البحث لعدد 1 الاعب عمدياً، وكان من أهم النتائج انه توجد علاقة ارتباطية دالة إحصائية بين مستوى الأداء المهارى المركب وجميع الجمل الخططية قيد البحث.

وقام أحمد أمين أحمد الشافعي ( . . . r م) (r) بدراسة بعنوان تطوير الاعداد الفني لناشئي كرة القدم وقد إستخدم الباحث المنهجين الوصفي و التجرببي على عينـة قوامها ع ؛ ناشئ ، وكان من أهم النتائج انه توجد فروق دالة احصـائياً بين قياسات المجموعة التجريبية في المتغيرات المهاريـة ولصـالح القياس البعدي.

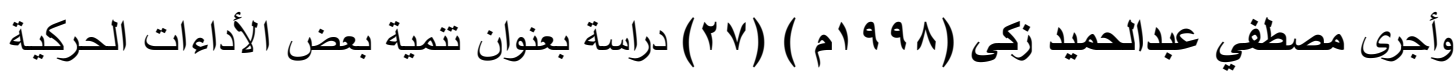
المـركبـة- المندمجة - الهجومية لناشئي كرة القدم ، وقد إستخدم الباحث المنهج التجريبي على عينـة قوامها ب r ناشئ تحت ^/ سنة، وكان من أهم النتائج أن البرنامج التدربي يؤثر إيجابياً على تنمية دقة وسرعة الأداءات الحركية المركبة - المندمجة- الهجوميــة لعينــة البحث. وقد إستفاد الباحثان من هذه الدراسات فى التعرف على أفضل الإجراءات المناسبة لطبيعة هذا البحث بداية من صياغة هدف البحث وفروضه والمنهج المستخدم والأسلوب الإحصائى وانتهاءاً بمناقشـة النتائج وصياغة الاستخلاصات والتوصيات. أولاً: منهج البحث: استخدم الباحثان المنهج التجريبي نظراً لملاعمته لنوع وطبيعة هذا من خلال التصميم التجريبي لمجموعة تجربيية واحدة والذي يعتمد على القياس القبلي والبعدي • 


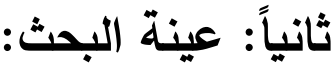

اشتملت عينة البحث على ناشئ كرة القدم تحت 1 ا سنة تم اختيارها عمدياً من نادى الثرقية

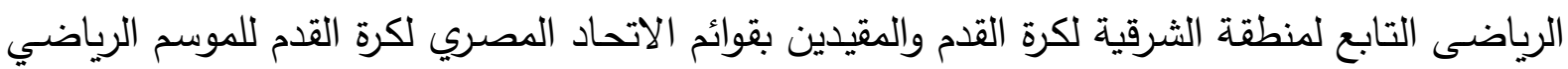

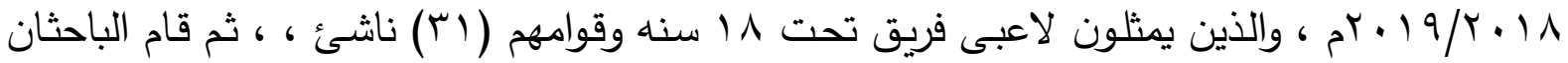

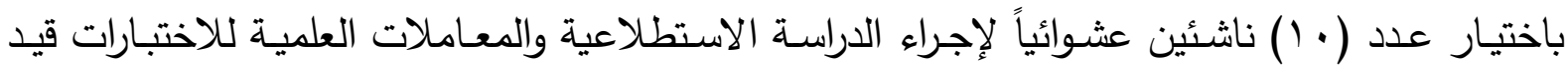

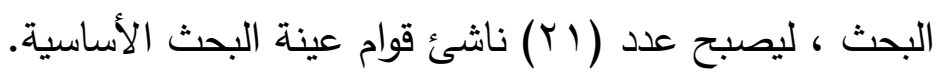
ثالثا : تجانس عينة البحث . قام الباحثان بحساب التجانس لعينة البحث عن طريق معامل الالتواء بدلالة كل من المتوسط الحسابي والوسيط والانحراف المعياري لعينة البحث في (متغيرات النمو - المتغيرات البدنية - المتغيرات المهارية

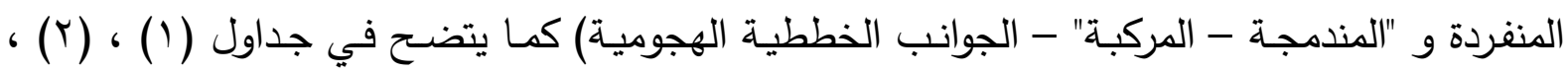
$\cdot(0) \cdot(\varepsilon) \cdot(r)$

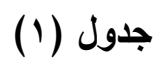

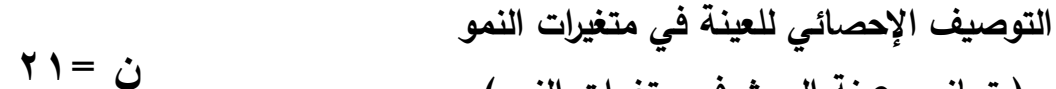

\begin{tabular}{|c|c|c|c|c|c|c|}
\hline معامل الالتواء & الالمياري & الوسيط & الحستوسطي & القياس & المتغيرات & p \\
\hline $1, Y 7-$ & $\cdot, \leqslant V$ & 17,1 & $17,7 \varepsilon$ & سنة & العمر الزمني & 1 \\
\hline •, Ir & 1,10 & $\varepsilon$ & $\varepsilon, 1 \leqslant$ & سنة & العمر التدريبي & $r$ \\
\hline$\cdot, ., \varepsilon$ & ๑ & iv. & $179,0 \mathrm{~V}$ & سم سم & طول الجسم & $r$ \\
\hline 1,99 & $\Lambda, 14$ & $\uparrow \Lambda, \xi$ & $\checkmark \wedge, \wedge \vee$ & كجم & وزن الجسم & $\varepsilon$ \\
\hline
\end{tabular}

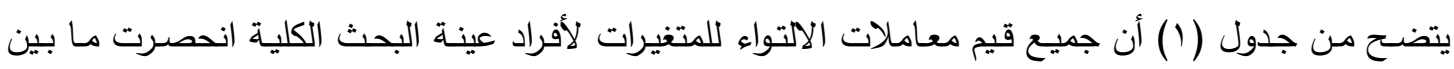

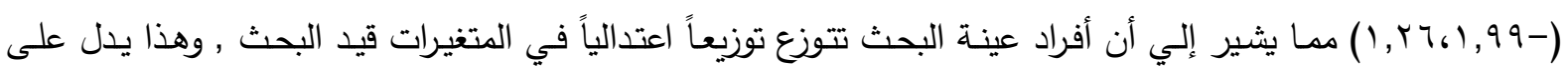

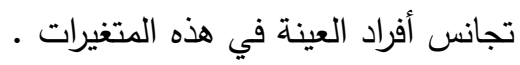


جدول (r)

التوصيف الإحصائي للعينة في المتغيرات البدنية

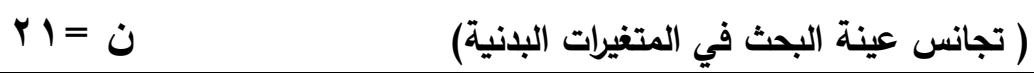

\begin{tabular}{|c|c|c|c|c|c|c|}
\hline معامل الالتواء & الالحعراف & الوسيط & الحستابي & والقياس & المتغيرات & م \\
\hline$\cdot, \cdot r-$ & $\cdot, r$. & $\varepsilon, 7$. & $\varepsilon, 89$ & ثانية & سرعه انتقالية & 1 \\
\hline זם, & 1,14 & $r<, q 9$ & $r_{0, .} .0$ & ثانية & تحمل السرعة & r \\
\hline •, & $1, .7$ & $r 4,0$ & $r q, r r$ & سم & قدرة عضلية & r \\
\hline$\cdot, \mathrm{V} \cdot-$ & $1,1 \mathrm{~V}$ & $v, 0$ & $r, I V$ & سم & مرونة & $\varepsilon$ \\
\hline ., rq & r & 9,09 & 9,00 & ثانية & رشاقة & 0 \\
\hline
\end{tabular}

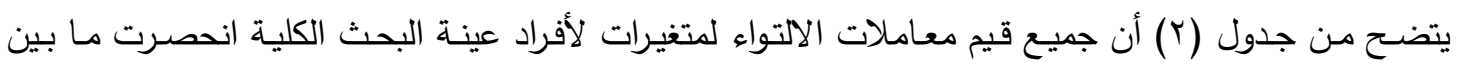

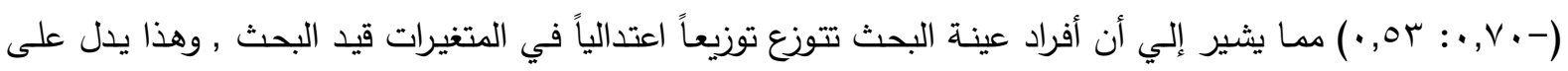
تجانس أفراد العينة في هذه المتغيرات .

جدول (ז)

التوصيف الإحصائي للعينة الكلية في مستوى المهارات الفردية

( تجانس عينة البحث في مستوى المهارات الفردية)

\begin{tabular}{|c|c|c|c|c|c|c|}
\hline معامل الالتواء & الالمعراف & الوسيط & الحستوسط & القياس & المتغيرات & p \\
\hline $1,1 \mathrm{~V}$ & $v, \cdot v$ & ○. & or,vo & درجة & السيطرة علي الكرة & 1 \\
\hline $1, r^{4}$ & $r, \Delta V$ & 7. & $71,0$. & درجة & التمرير المتنوع & r \\
\hline $1, \cdot v$ & 7,91 & 7. & Ir,O. & درجة & دقة رمية التماس & r \\
\hline$\cdot, \wedge$ & $V, \leqslant \Lambda$ & 7. & Tr & درجة & تصويب الكرة الي جزء & 0 \\
\hline
\end{tabular}

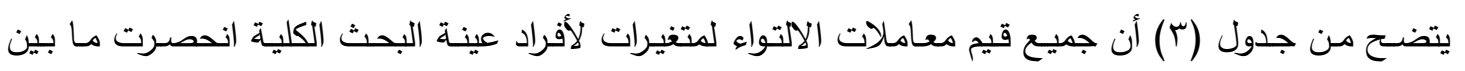

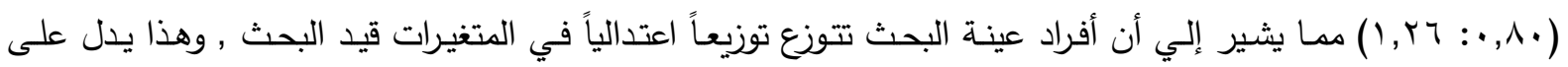




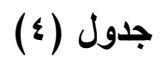

التوصيف الإحصائي للعينة في مستوى المتغيرات المهارية المندمجة - المركبة

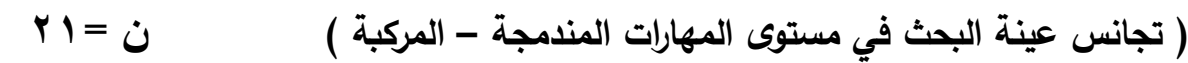

\begin{tabular}{|c|c|c|c|c|c|c|}
\hline معامل الالتواء & الالانحراف & الوسيط & المستوسط & القياس & المتغيرات & $p$ \\
\hline $1,1 Y-$ & $\cdot, r q$ & 7 & $\bullet, \wedge$ & ثانية & الاستلام ثم المرير & 1 \\
\hline$\cdot, \mathrm{v}_{0}$ & 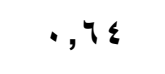 & $9, r_{0}$ & $9,0 Y$ & 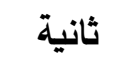 & الاستلام ثم الجري ثم التمرير & r \\
\hline .,94 & $\cdot, 4$ & 9,4 & $9, \wedge 0$ & 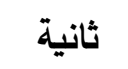 & الاستلام ثم المراوغة ثم التمرير & $r$ \\
\hline$\cdot, \mathrm{Va}$ & $\cdot, \leqslant 0$ & $1 \cdot, \mathrm{va}$ & $1 \cdot, 91$ & 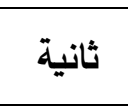 & 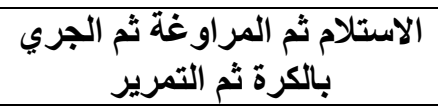 & $\varepsilon$ \\
\hline די & $\cdot, \mathrm{r} \wedge$ & 0,90 & $7, \cdot r$ & ثانية & \multirow{2}{*}{ الاستلام ثم التصويب } & \multirow{2}{*}{0} \\
\hline$\cdot, \wedge \vee$ & $v, \varepsilon r$ & r & Y Y,YO & درجة ل & & \\
\hline$\cdot, \mathrm{v} 0-$ & $\cdot, \leqslant 1$ & 9,11 & $q, \cdot v$ & 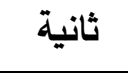 & \multirow{2}{*}{ الاستّلام ثم الجري ثم التصويب } & \multirow{2}{*}{7} \\
\hline$\cdot, \wedge 9$ & $0, \wedge \vee$ & r. & m, vo & 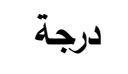 & & \\
\hline$\cdot, 9 \vee-$ & 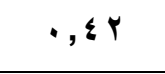 & $9, \xi$. & $9, Y^{4}$ & 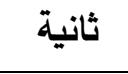 & \multirow{2}{*}{ الاستلام ثم المراوغة ثم } & \multirow{2}{*}{$v$} \\
\hline $1, \mathrm{VT}$ & $\Lambda, 44$ & r. & ro & درجة ل & & \\
\hline$\cdot, \wedge \mathrm{V}$ & • & 11,10 & $11, r v$ & 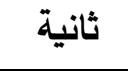 & \multirow{2}{*}{ الاستلامثر ثُ المر التصويب ثم الجري } & \multirow{2}{*}{$\wedge$} \\
\hline $1, \mathrm{rA}$ & ד, Q4 & r. & $r r, O$. & درجة ل & & \\
\hline
\end{tabular}

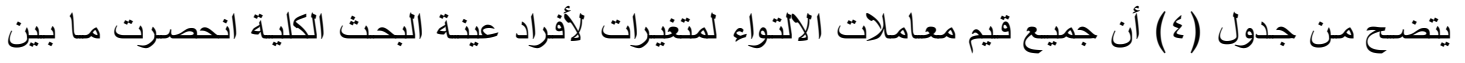

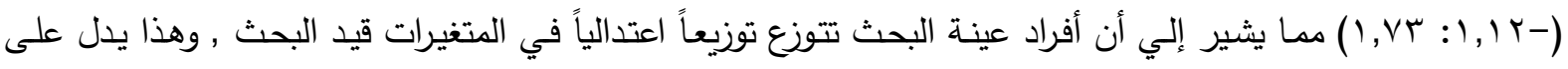




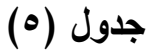

التوصيف الإحصائي للعينة في مستوى الجوانب الخططية

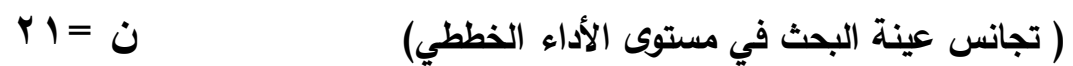

\begin{tabular}{|c|c|c|c|c|c|c|c|}
\hline الالتواء & الالحعراف & الوسيط & الحستبي & القياس & المتغيرات & الخطوانة & p \\
\hline$\cdot, \Upsilon^{\prime} \wedge$ & $\cdot, \wedge 0$ & $\varepsilon$ & $r, q$. & درجة & العقق في الدفاع & \multirow{3}{*}{$\begin{array}{l}\text { "हn" } \\
\underline{E} \\
\underline{E}\end{array}$} & \multirow{3}{*}{1} \\
\hline • & $\cdot, \mathrm{V} \varepsilon$ & r & $1, \wedge 0$ & درجة & التأخير في الدفاع & & \\
\hline., 11 & $\cdot, \nabla r$ & $r$ & $r$ & درجة & الاتزان في الدفاع & & \\
\hline $1, .9$ & - 9 \& & $\mid r, \leqslant \Lambda$ & IY,TV & ثانية & \multirow{2}{*}{ الأداء رقطم (آ) الزوجي } & \multirow{14}{*}{ E } & \multirow{14}{*}{$r$} \\
\hline $1,1 V$ & - 94 & 1 & $1, .0$ & درجة & & & \\
\hline$\cdot, r v-$ & - & 11,19 & $11, \cdot v$ & ثانية & \multirow{2}{*}{ الأداء الخططي الزوجي } & & \\
\hline דוז, & • & 1 & I,rT & درجة & & & \\
\hline$\cdot, \wedge 1-$ & $\cdot, \wedge 1$ & $1 r, v 4$ & $1 \%, \varepsilon$ & ثانية & \multirow{2}{*}{ الأداء الخططي الزوجي } & & \\
\hline r & $\cdot, \wedge \vee$ & 1 & $1, \leqslant \wedge$ & درجة & & & \\
\hline $1, \cdot r$ & $\cdot 94$ & $1 \leqslant, V \leqslant$ & $1 \leqslant, 91$ & ثانية & \multirow{2}{*}{ الأداء الخططي الزوجي (๕) } & & \\
\hline$\cdot, \cdot 1-$ & (9) & 1 & $1,0 Y$ & درجة & & & \\
\hline $1, .9$ &.,$\infty 0$ & $1 Y, 00$ & Ir,Vr & ثانية & \multirow{2}{*}{ 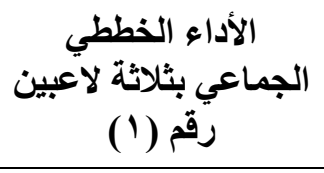 } & & \\
\hline Vע & $\cdot, \mathrm{V}_{0}$ & 1 & $1, \varepsilon r$ & درجة & & & \\
\hline$\cdot, r V-$ & $\cdot, 7$ & $1 Y, 74$ & $14, .9$ & ثانية & \multirow{2}{*}{ 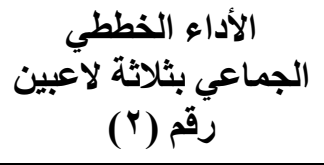 } & & \\
\hline$\cdot, \leqslant \wedge$ & $\cdot v \varepsilon$ & 1 & $1, \leqslant \wedge$ & درجة & & & \\
\hline •, \& & $\cdot, 7$ & $1 \varepsilon, . r$ & $1 \leqslant, .4$ & ثانية & \multirow{2}{*}{ 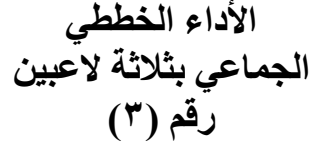 } & & \\
\hline$\cdot, 99$ & $\cdot, 91$ & 1 & 1,19 & درجة & & & \\
\hline
\end{tabular}

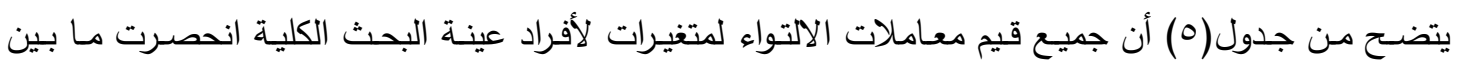

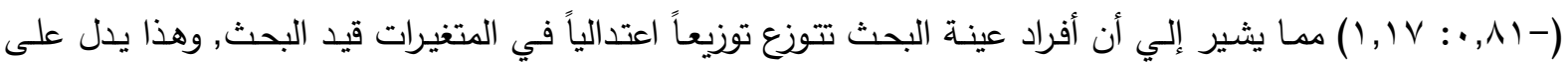

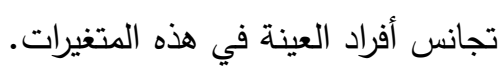


رابعاً: وسائل جمع البيانات:

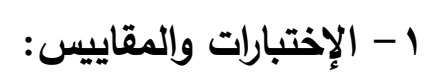

- ق قياس الطول والوزن بإستخدام جهاز الرستاميتر والميزان الطبي. - قياس المتغيرات البدنية بإستخدام الإختبارات البدنية . - قياس المتغيرات المهارية بإستخدام الإختبارات المهارية( الفردية - المندمجة " المركبة" ). - قياس المتغيرات الخططية بإستخدام الإختبارات الخططية (الدفاعية - الهجومية) .

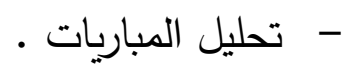

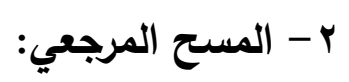

قام الباحثان بالإطلاع على العديد من المراجع العلمية الحديثة والتي لها علاقة وثيقة بمتغيرات البحث وكذلك الدراسات المرتبطة بالبحث واستعانا بالموقع الرسمى لاتحاد مكتبات الإنبات الجامعات المصرية

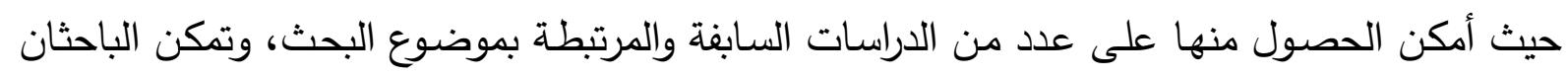

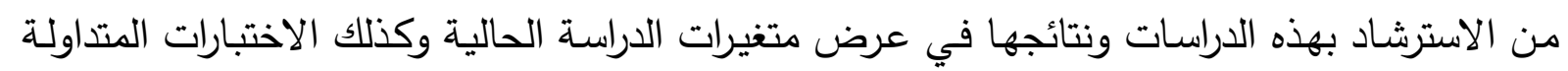
والمناسبة لقياس هذه المتغيرات.

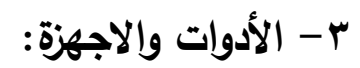
قام الباحثان بإجراء القياسـات والإختبارات المستخدمة- قيد البحث - مستخدماً الأجهـزة والأدوات

$$
\text { ميزان طبى معاير لقياس الوزن (كجم). }
$$

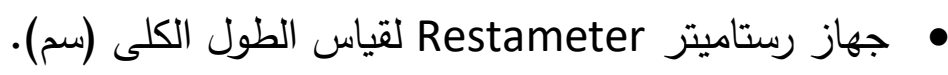

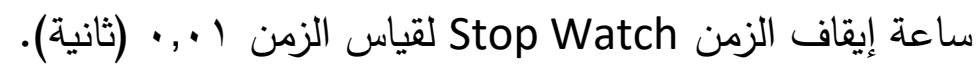
هريط قياس مدرج بالسنتيمتر . ملعب كرة قدم كرات قدم.

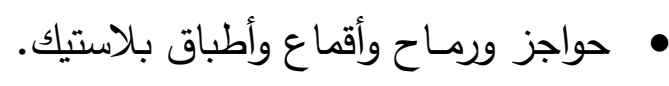
• • • • صفارات. شرائط قماش لتقسيم الملعب. 
خامساً: المعاملات العلمية للاختبارات والمقاييس المستخدمة:

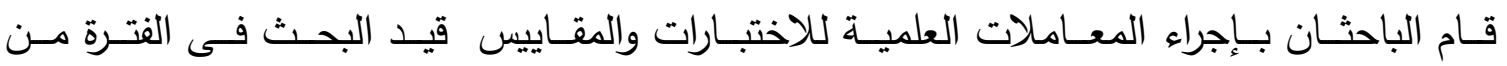

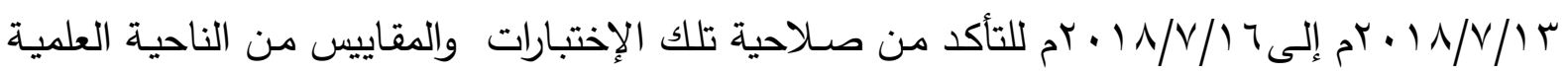

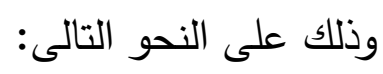

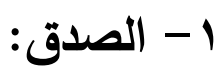

لإيجاد معامل الصدق قام الباحث بتطبيق صدق التمايز، حيث قام الباحثان بإجراء القياسات البدنية

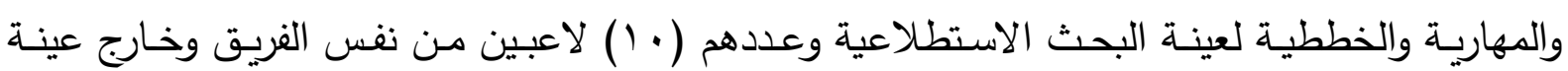

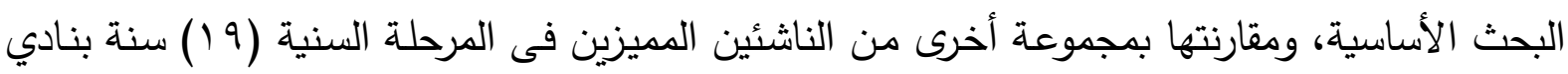

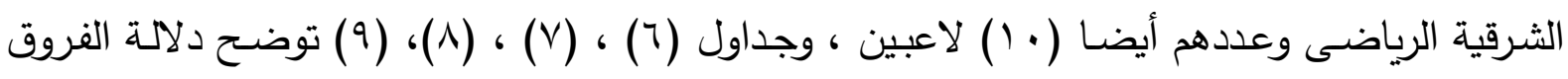

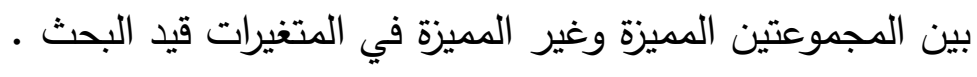

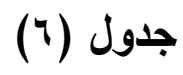

دلالة الفروق بين المجموعتين الغير المميزة والمميزة

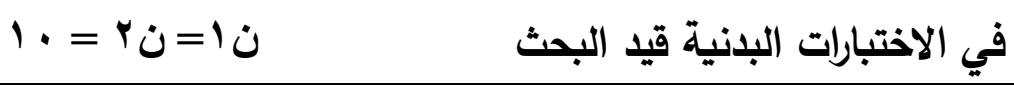

\begin{tabular}{|c|c|c|c|c|c|c|c|}
\hline \multirow{2}{*}{ قالمحسو (ت) } & \multicolumn{2}{|c|}{ المجموعة الغير } & \multicolumn{2}{|c|}{ المجموعة المميزة } & \multirow{2}{*}{ والقياس } & \multirow{2}{*}{ المتغيرات } & \multirow{2}{*}{ r } \\
\hline & $r \varepsilon \pm$ & س r & $\varepsilon^{\prime}$ & س & & & \\
\hline$r, \leqslant \uparrow-$ & $\cdot, v_{1}$ & ( & ד & $r, q 0$ & ثانية & سرعه انتقالية & 1 \\
\hline $7, \leqslant \vee-$ & $1, r v$ & $\mu q, O \Lambda$ & $\cdot, \mathrm{VV}$ & צ & ثانية & تحمل السرعة & $r$ \\
\hline$V, r r$ &., 99 & $r v, q$. & $\cdot, \vee \wedge$ & r., . & سم & قرة عضلية & r \\
\hline$r, v$. & $\cdot, v r$ &., 9 & 1,00 & $r$ & سم & مرونة & $\varepsilon$ \\
\hline$\varepsilon, \varepsilon V-$ &., 91 & $1 ., 89$ & $\cdot, V$ & $\wedge, \vee \vee$ & ثانية & رشاقة & 0 \\
\hline
\end{tabular}

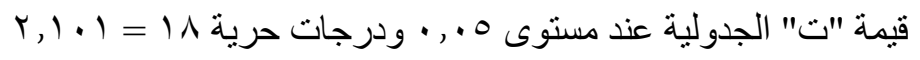

يتضـح من جدول (T) وجود فروق ذات دلالـة إحصـائية بين المجموعة المميزة والمجموعة الغير المميزة في

اختبارات القدرات البدنية قيد البحث لصالح المجموعة المميزة ، مما يعطي دلالة مباشرة علي صدق الاختبارات المستخدمة 


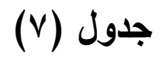

التوصيف الإحصائي للعينة الكلية في مستوى المهارات الفردية

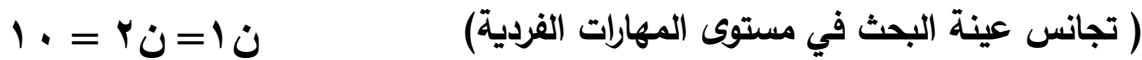

\begin{tabular}{|c|c|c|c|c|c|c|c|}
\hline \multirow{2}{*}{ قايمة (ت) } & \multicolumn{2}{|c|}{ المجموعة الغيز } & \multicolumn{2}{|c|}{ المجموعة المميزة } & \multirow{2}{*}{ القياس } & \multirow{2}{*}{ المتغيرات } & \multirow[b]{2}{*}{$p$} \\
\hline & $r \varepsilon^{ \pm}$ & س & $\varepsilon^{ \pm}$ & سا & & & \\
\hline 0,00 & זידוי & $0 \leqslant, \ldots$ & $0, \mu_{\Lambda}$ & $79, \ldots$ & درجة & السيطرة علي الكرة & 1 \\
\hline 0,79 & $\varepsilon, \ldots$ & $i r, \ldots$ & $r, .$. & $v_{1}, \ldots$ & درجة & التمرير المتنوع & r \\
\hline T,YA & 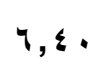 & $\pi, \ldots$ & $\varepsilon, \ldots$ & $\vee \wedge, \ldots$ & درجة & دقة رمية التماس & r \\
\hline $0, \wedge \Gamma$ & $v, \ldots$ & $\because 1, \ldots$ & $\uparrow, \ldots$ & $\vee \wedge, \ldots$ & درجة & تصويب الكرة الي جزء & 0 \\
\hline
\end{tabular}

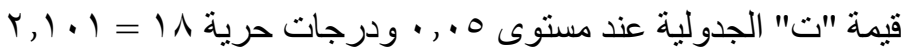

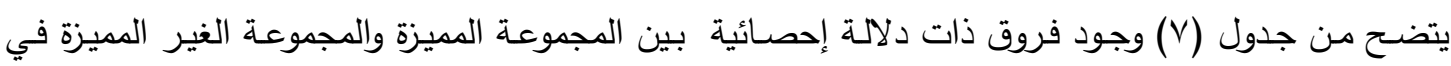

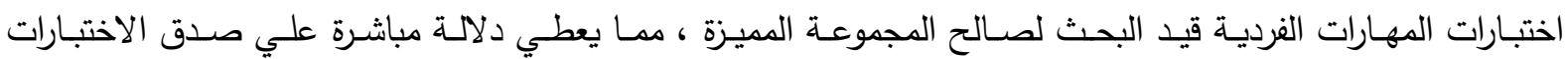
المستخمة في البحث 
جدول (^)

التوصيف الإحصائي للعينة في مستوى المتغيرات المهارية المندمجة - المركبة

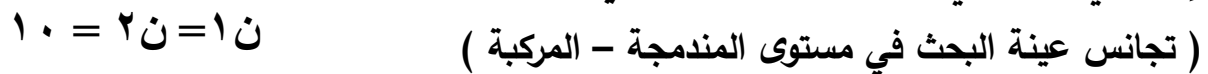

\begin{tabular}{|c|c|c|c|c|c|c|c|}
\hline \multirow{2}{*}{ قالمسمة (ت) } & \multicolumn{2}{|c|}{ المجموعة الغير } & \multicolumn{2}{|c|}{ المجموعة المميزة } & \multirow{2}{*}{ القياس } & \multirow{2}{*}{ المتغيرات } & \multirow{2}{*}{ r } \\
\hline & $r \varepsilon \pm$ & س & $1 \varepsilon^{ \pm}$ & 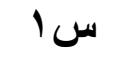 & & & \\
\hline $0,1 \leqslant$ & $\cdot, r \leq$ & $0, \wedge \mu$ & $\cdot$, , & $0,1 \leq$ & ثانية & الاستلام ثم المرير & 1 \\
\hline $0, r \leqslant$ & $\cdot, 70$ & $9,7$. & 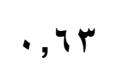 & $9, \cdot 1$ & ثانية & الاستلام ثم الجري ثم التمرير & r \\
\hline $0, r \mu$ &., 70 & $9, \wedge 9$ & $\cdot, £ \vee$ & $\Lambda, \diamond \vee$ & ثانية & الاستلام ثم المراوغة ثم التمرير & r \\
\hline 0,01 & $\cdot, \leqslant \wedge$ & $1 \cdot, 97$ & $\cdot, 0 \leqslant$ & $9, v_{1}$ & 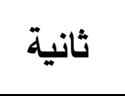 & الاستلام ثمث المراوغة ثمثم التمرير الجري & $\varepsilon$ \\
\hline $0, \cdot \varepsilon$ & $\cdot, \vee \wedge$ & $\bullet, \vee \wedge$ & $\cdot, \leqslant 9$ & $\varepsilon, r$ & 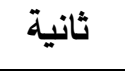 & \multirow{2}{*}{ الاستلام ثم التصويب } & \multirow{2}{*}{0} \\
\hline $7, O r$ & $v, 1 \leq$ & $r q, \ldots$ & $9,1 r$ & $r r, \ldots$ & درجة & & \\
\hline 7,10 & $\cdot, \varepsilon V$ & $9,1$. & $\cdot, \leqslant \varphi$ & $\vee, \wedge 0$ & ثانية & \multirow{2}{*}{ الاستلام ثم الجري ثم التصويب } & \multirow{2}{*}{7} \\
\hline $0, v_{1}$ & $7, \cdots$ & $r r, \ldots$ & $7, \cdots$ & $r r, \ldots$ & 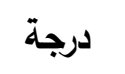 & & \\
\hline $0, \wedge 1$ & $\cdot, \leqslant \mu$ & 9,10 & $\cdot, \leqslant \leq$ & $\wedge,+1$ & 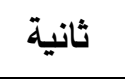 & \multirow{2}{*}{ الاستلام ثم المراوغة ثم } & \multirow{2}{*}{ V } \\
\hline 0,79 & $\wedge, \cdots$ & $r \varepsilon, \ldots$ & $11, r q$ & $\varepsilon q, \cdots$ & 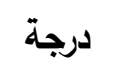 & & \\
\hline 0,97 & $\cdot, \leqslant 0$ & $11, r r$ & $\cdot, \leqslant 7$ & $1 \cdot, 11$ & 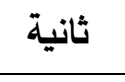 & \multirow{2}{*}{ بالاستلام ثم المراوغة ثم التصويب الجري } & \multirow{2}{*}{$\wedge$} \\
\hline $0, r \varepsilon$ & $1, \cdot 9$ & $r \bullet, \ldots$ & $7, \cdots$ & $\varepsilon r, \cdots$ & درجة & & \\
\hline
\end{tabular}

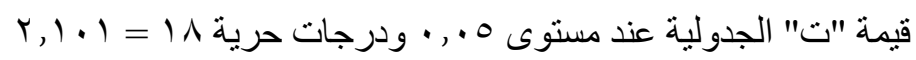

يتضح من جدول (^) وجود فروق ذات دلالة إحصائية بين المجموعة الميزة والمجموعة الغير الميزة في

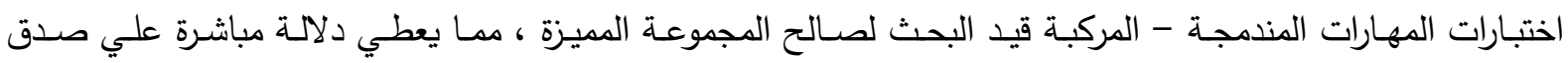

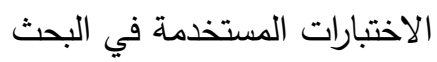


جدول (9) (9)

التوصيف الإحصائي للعينة في مستوى الجوانب الخططية

( تجانس عينة البحث في مستوى الأداء الخططي)

\begin{tabular}{|c|c|c|c|c|c|c|c|c|}
\hline \multirow{2}{*}{ قالمحسوبة (ت) } & \multicolumn{2}{|c|}{ المجموعة الغير } & \multicolumn{2}{|c|}{ المجموعة المميزة } & \multirow{2}{*}{ القياس وحدة } & \multirow{2}{*}{ المتغيرات } & \multirow{2}{*}{ الخطوبة انبة } & \multirow{2}{*}{ p } \\
\hline & $1 \varepsilon \pm$ & س & $1 \varepsilon^{ \pm}$ & س & & & & \\
\hline$V, r q$ & $\cdot, \wedge \uparrow$ & $\varepsilon, 1$. & $\cdot, \wedge \uparrow$ & 7,1 . & درجة & العمق في الدفاع & & \\
\hline$V, r^{-}$ & •, & 1,9 . & $\cdot, \wedge \uparrow$ & $r, q$. & درجة & التأخير في الافاع & & 1 \\
\hline$\varepsilon, \varepsilon$. & $\cdot, O r$ & $r, 0$. & •, Or & $r, 0$. & درجة & الاتزان في الدفاع & & \\
\hline$\varepsilon, \wedge-$ & דיר & $1 r, 1 \varepsilon$ & $\cdot, v_{1}$ & $1 \cdot, \wedge \varepsilon$ & ثانية & الأداء الخططي الزوجي & & \\
\hline Y,r & $1,7 \varepsilon$ & 1,0 & $1, V^{4}$ & $r, r$ & درجة & رفم & & \\
\hline$r, r_{1-}$ & • & $11,\{1$ & 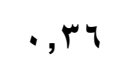 & $9, \vee r$ & ثانية & الأداء الخططي الزوجي & & \\
\hline$\varepsilon, 1$ & $\cdot, 9 \leq$ & $\cdot, \mathrm{V}$ & 1,174 & $r, r$ & درجة & 0 & & \\
\hline$\bullet, \wedge \bullet-$ & $\cdot, \circ \mathrm{V}$ & $1 r, \cdot 1$ & $\cdot, 11$ & $11, .0$ & ثانية & ل للي الزوجي & & \\
\hline r,97 & $\cdot, 90$ & $\cdot, \mathrm{V}$ & 1,79 & $r, 1$ & درجة & & & \\
\hline $7, Y 7-$ & $\cdot, O \mathrm{~V}$ & $\mid 7, v 1$ & $\cdot, r \Lambda$ & $\mid \varepsilon, r_{1}$ & ثانية & الأداء الخططي الزوجي & & $r$ \\
\hline$\varepsilon, \varepsilon$ & 1,10 & 1 & $1, r 9$ & $r, \varepsilon$ & درجة & 09 & & \\
\hline$r, 90-$ & $1, \leqslant 7$ & $|r, 0|$ & $\cdot, \leqslant 9$ & $1 \cdot, \wedge \mathrm{V}$ & ثانية & الأداء الخططح & & \\
\hline$r, 9 \wedge$ & $\cdot, 90$ & $\cdot, \mathrm{V}$ & $1, \vee \wedge$ & $r, q$ & درجة & رقم (1) & & \\
\hline $0, \cdot v-$ & $\cdot, V Y$ & Ir, Tr & r & $11, r$. & ثانية & الأداء الخططي . ـ & & \\
\hline r, r & $\cdot, \wedge r$ & 1 & $1, \leqslant 1$ & $r, \wedge$ & درجة & رَّم (r) & & \\
\hline$\checkmark, \wedge Y-$ & r & IV & $\cdot, 9 r$ & $1 \Gamma, 1 \varepsilon$ & ثانية & الأداء الخططي & & \\
\hline$r, r q$ & $1, \times 9$ & 1,9 & $1, r \varepsilon$ & T, t & درجة & رقم (r) & & \\
\hline
\end{tabular}

يتضح من جدول (9) وجود فروق ذات دلالة إحصائية بين المجموعة المميزة والمجموعة الغير الميزة في الهي

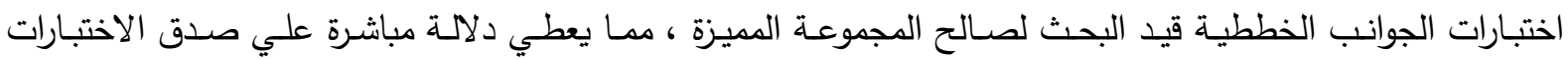


قام الباحث بحساب ثبات الاختبارات باستخدام طريقة تطبيق الاختبارات ثم إعادة تطبيقها مرة أخرى

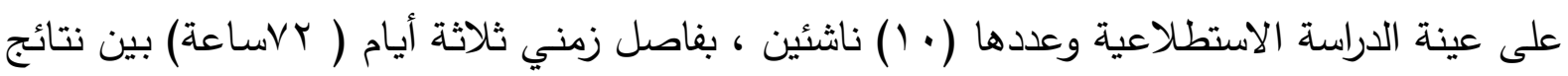

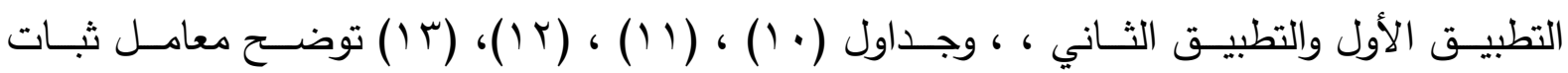

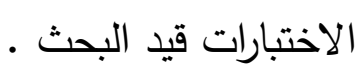

\section{جدول (·) (1) (ل)}

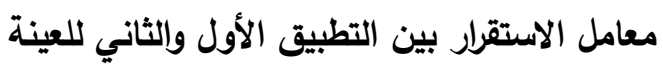

$1 \cdot=ن$ الاستطلاعية في الاختبارات البدنية (قيد البحث)

\begin{tabular}{|c|c|c|c|c|c|c|c|}
\hline \multirow{2}{*}{ قيمة (ر) } & \multicolumn{2}{|c|}{ التطبيق الثاني } & \multicolumn{2}{|c|}{ التطبيث الأول } & \multirow{2}{*}{ وحدة القياس } & \multirow[b]{2}{*}{ المتغيرات } & \multirow[b]{2}{*}{ r } \\
\hline & $r \varepsilon \pm$ & س & $1 \varepsilon^{ \pm}$ & س & & & \\
\hline$* ., 909$ & $\cdot, V r$ & $\varepsilon, 77$ & $\cdot, v_{1}$ & \& & ثانية & سرعه انتقالية & 1 \\
\hline$*$. , $79 \vee$ & $\cdot, 9 \leq$ & ه & $1, r V$ & N & ثانية & تحمل السرعة & $r$ \\
\hline$*,, \vee \vee \wedge$ & 1,ro & $r v, q$ &., 99 & $r v, q$. & سم & قدرة عضلية & r \\
\hline$* ., 917$ & $\cdot, \vee \vee q$ & $\cdot, \wedge$ & $\cdot, \mathrm{Vr}$ & $\cdot, 9$ & سم & مرونة & $\varepsilon$ \\
\hline$* ., 791$ & $1, r_{0}$ & $1 \cdot, \cdot 1$ &., 91 & $1 ., 89$ & ثانية & رشاقة & 0 \\
\hline
\end{tabular}

قيمة "ر" الجدولية عند مستوى 0 . , • ودرجات حرية $9=$

يتضح من جدول( • (1) وجود علاقة إرتباطية ذات دلالمة إحصائية عند مستوى معنويـة ه ., • ودرجات حريـة

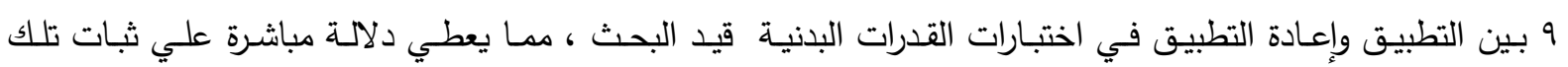


جدول (1)

التوصيف الإحصائي للعينة الكلية في مستوى المهارات الفردية

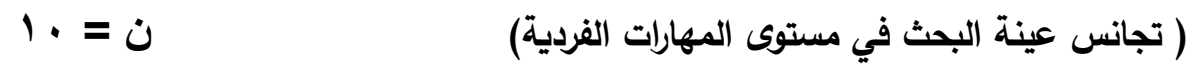

\begin{tabular}{|c|c|c|c|c|c|c|c|}
\hline \multirow{2}{*}{ قايمة (ت) } & \multicolumn{2}{|c|}{ التطبيق الثاني } & \multicolumn{2}{|c|}{ التطبيق الأول } & \multirow{2}{*}{ القياس } & \multirow{2}{*}{ المتغيرات } & \\
\hline & $r \varepsilon^{ \pm}$ & سץ & $1 \varepsilon^{ \pm}$ & س & & & \\
\hline$* \cdot, \wedge 9$ & $8, \times 1$ & $\Delta, \ldots$ & ז, & $0 \leqslant, \ldots$ & درجة & السيطرة علي الكرة & 1 \\
\hline$*, q \leqslant$ & $\uparrow, \xi$. & (r,... & $\varepsilon, \ldots$ & $r, \ldots$ & درجة & التمرير المتنوع & r \\
\hline$* \cdot, \wedge 9$ & אי, & $I \varepsilon,$. & $8, \xi$ & 策, . & درجة & دقة رمية التماس & r \\
\hline$\because \cdot, q r$ & $v, \leqslant \Lambda$ & $\pi, \ldots$ & $v, \ldots$ & $\pi, \ldots$ & درجة & تصويب الكرة الي جزء & 0 \\
\hline
\end{tabular}

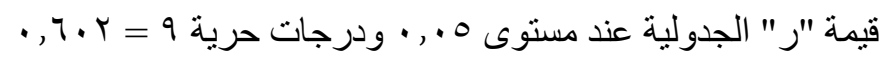

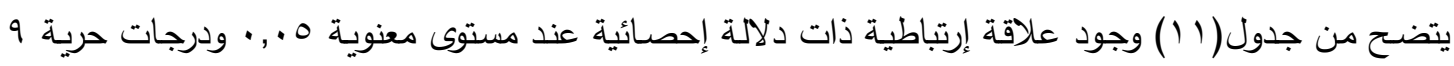

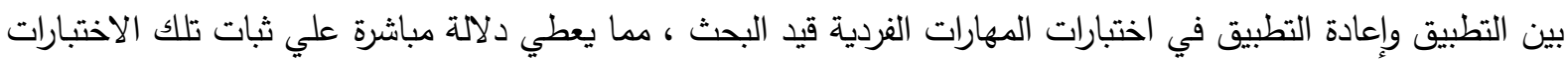




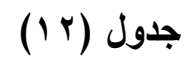

التوصيف الإحصائي للعينة في مستوى المتغيرات المهارية المندمجة - المركبة

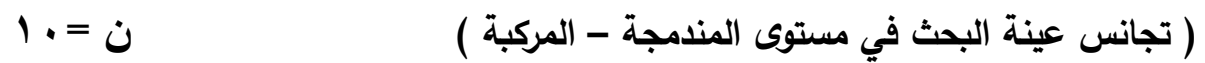

\begin{tabular}{|c|c|c|c|c|c|c|c|}
\hline \multirow{2}{*}{ القيمسة (ر) } & \multicolumn{2}{|c|}{ التطبيق الثاني } & \multicolumn{2}{|c|}{ التطبيق الأول } & \multirow{2}{*}{ القياس } & \multirow{2}{*}{ المتغيرات } & \multirow[b]{2}{*}{ r } \\
\hline & r & س سץ & $1 \varepsilon^{ \pm}$ & س س & & & \\
\hline$* \cdot, q \leq$ & • & $0, \vee \wedge$ & צ & $0, \wedge r$ & ثانية & الاستلام ثم المرير & 1 \\
\hline$* \cdot, 91$ &., 01 & $9,0 \leq$ & סו, & 9,7 & ثانية & الاستلام ثم الجري ثم التمرير & r \\
\hline$*, q$. & $\cdot$, OV & $Q, \wedge \vee$ & סי, & $9, \wedge 9$ & ثانية & الاستلام ثم المراوغة ثم التمرير & r \\
\hline$*, \wedge \wedge$ & $\cdot, 7$ & $1 \cdot, \mathrm{Va}$ & $\cdot$, , « & $1 ., 99$ & ثانية & الاستلام ثُم المر التمرية ثم الجري & $\varepsilon$ \\
\hline$*, 9 \leq$ & $\cdot, 71$ & 0,01 & $\cdot, \mathrm{v \wedge}$ & $0, \vee \wedge$ & ثانية & & 0 \\
\hline$* \cdot, \wedge \varepsilon$ & $8,0 \mathrm{~V}$ & ro & $v, 1 \leqslant$ & $r q, \ldots$ & درجة ل & & \\
\hline$*, 9 r$ & $\cdot, \leqslant 0$ & $9, \cdot \varepsilon$ & $\cdot, \leqslant \vee$ & $9,1$. & ثانية & ע) & \\
\hline$* \cdot, \wedge \wedge$ & $8, \xi$ & $r r, \ldots$ & $\checkmark, \cdots$ & $r r, \ldots$ & درجة & 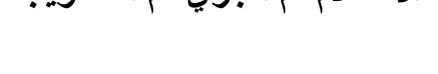 & \\
\hline$*, a r$ & ., \& & $9,1 \leq$ & r & 9,10 & ثانية & الاستلام ثم المراوغة ثم & \\
\hline$*, 9 \mu$ & $\wedge, .4$ & $r_{0}, \ldots$ & $\wedge, . \cdot$ & $r \leqslant, \ldots$ & درجة & ويب & \\
\hline$*, 91$ & $\cdot, \leqslant 0$ & $11, \mathrm{rq}$ & $\cdot, \leqslant 0$ & $11, r Y$ & ثانية & الاستلام ثم المراوغة ثم الجري & \\
\hline$* \cdot, \wedge 9$ & $9, \ldots$ & $r v, \ldots$ & $\wedge, .4$ & $r_{0}, \ldots$ & ل درجة & يب & \\
\hline
\end{tabular}

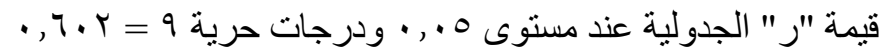

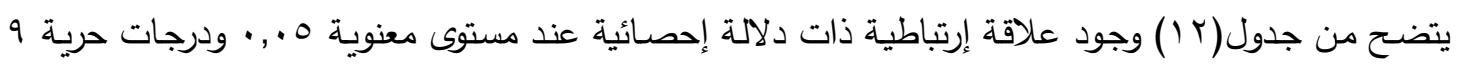

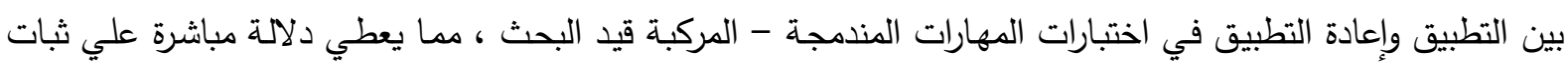




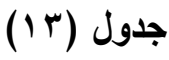

التوصيف الإحصائي للعينة في مستوى الجوانب الخططية

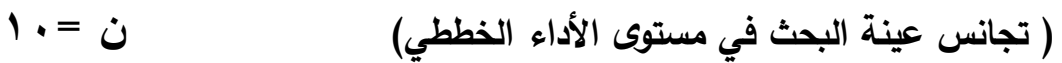

\begin{tabular}{|c|c|c|c|c|c|c|c|c|}
\hline \multirow{2}{*}{ قالمسمة (ر)ة } & \multicolumn{2}{|c|}{ التطبيق الثاني } & \multicolumn{2}{|c|}{ التطبيق الأول } & \multirow{2}{*}{ والقياس } & \multirow[b]{2}{*}{ المتغيرات } & \multirow{2}{*}{ الخططية الجب } & \multirow[b]{2}{*}{ r } \\
\hline & ' $\varepsilon^{ \pm}$ & سا & $\varepsilon^{ \pm}$ & س & & & & \\
\hline$*, \wedge \wedge$ & דוז, & $\varepsilon, \mu$. & די, • & $\varepsilon, 1$. & درجة & العمق في الدفاع & & \\
\hline$*, \wedge \mathrm{V}$ & דז & $r, 1$. & • & $1,9$. & درجة & التأخير في الدفاع & & 1 \\
\hline$*, q$. & $\cdot, \mathrm{v}$. & $r, \pi$. &.,$O Y$ & $r, 0$. & درجة & الاتزان في الدفاع & & \\
\hline$*_{\cdot}, \mathrm{V} \vee 0 \leq$ & $\cdot, 7$ & $\mid r, \& \wedge$ & די, & $1 \%, 1 \varepsilon$ & ثانية & الأداء الخططي & & \\
\hline 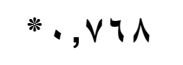 & $1,0 \mathrm{~V}$ & 1,7 & $1,7 \leqslant$ & 1,0 & درجة & & & \\
\hline$* ., 994$ & $1, \cdot r$ & $1 r, \cdot 1$ & 具, & $11, \varepsilon 1$ & ثانية & الأداء الخططي الزوجي & & \\
\hline$* \cdot, 9 \leq 4$ & $\cdot, 9 \mathrm{~V}$ & •, & • & $\cdot, \mathrm{V}$ & درجة & (r) & & \\
\hline$*,, \wedge \vee \vee$ & $\cdot$, rY & Ir,Ir & $\cdot, \mathrm{OV}$ & $1 \%, .1$ & ثانية & الأداء الخططي الزوجي & & \\
\hline$* \cdot, 9 \leq r$ & $\cdot, 91$ & $\cdot, \wedge$ & $\cdot, 90$ & $\cdot, \mathrm{v}$ & درجة & & & \\
\hline$*^{*}, \wedge \leq \vee$ & • & $\mid v, 1$. &., $\mathrm{OV}$ & 14,51 & ثانية & الأداء الخططي الزوجي & $E^{2}$ & r \\
\hline$*, r, r \cdot r$ & I, rv & 1,1 & 1,10 & 1 & درجة & & ᄂ & \\
\hline$*$, , qVr & 政 & Ir, & 1,84 & $1 r, 01$ & ثانية & الأداء الخططي & & \\
\hline *., ror & 1,01 & 1,7 &., 90 & $\cdot, \mathrm{V}$ & درجة & زقرم (1) & & \\
\hline$* \cdot, 9 \leq 0$ & $\cdot, 11$ & צ & $\cdot, V Y$ & Tr, & ثانية & الأداء الخططي & & \\
\hline$* \cdot, 9 r \mu$ & $\cdot, \wedge \wedge$ & $\cdot, 9$ & • & 1 & درجة & رقم (r) البيا & & \\
\hline$* \cdot, v \cdot q$ & $1, .9$ & $1 v, q 0$ & س r, & iv & ثانية & الأداء الخططي & & \\
\hline$*, T \leqslant \mu$ & 1, & $1, \Lambda$ & $1, \vee 9$ & 1,9 & درجة & رقق (r) & & \\
\hline
\end{tabular}

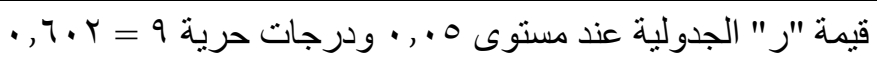

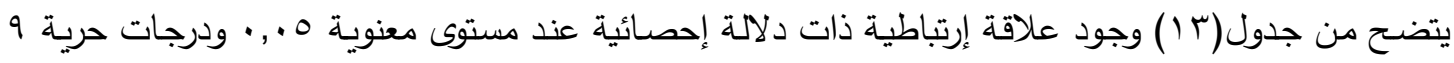

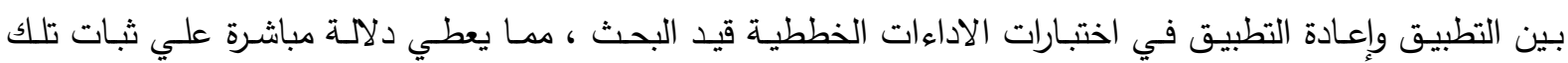


سادساً: الدراسة الاستطلاعية:

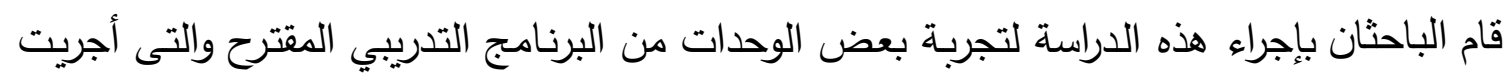

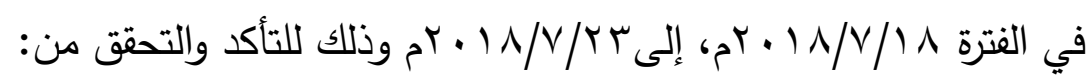

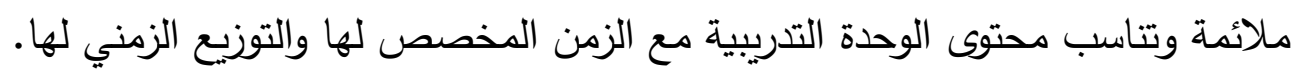

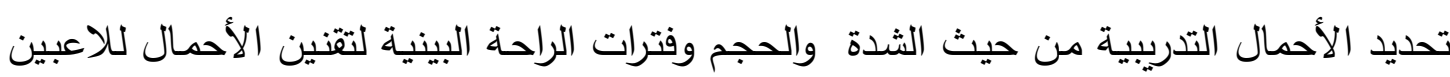
وفقاً لقدراتهم خلال تخطيط البرنامج التدريبي المقترح. قام الباحث باستخدام طريقة النسب المئوية في تقنين حمل التصريب.

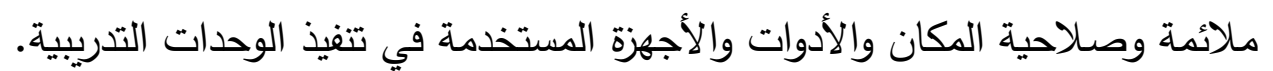

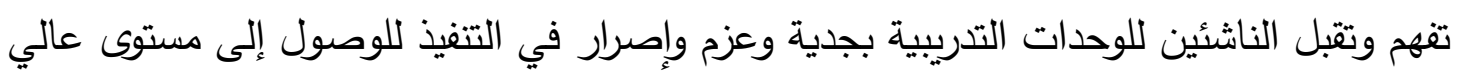

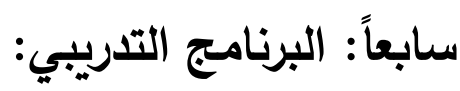

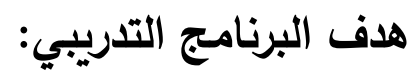

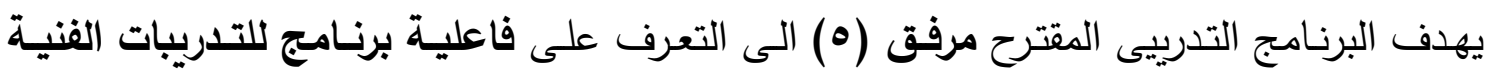
الإجبارية على تطوير أداء بعض الجوانب البننية والخططية لناشئي كرة القدام.

معايير وضع البرنامج التدريبي المقترح:

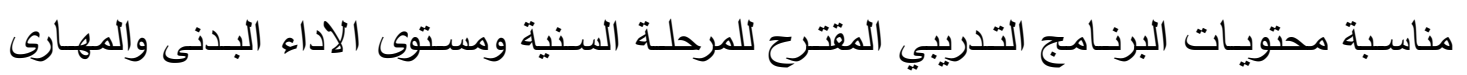
والخططي للناشئين عينة البحث.

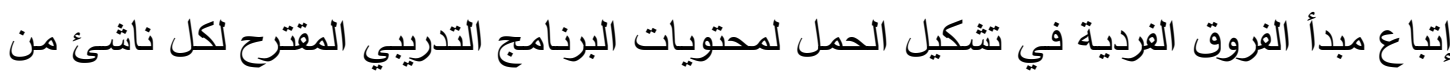

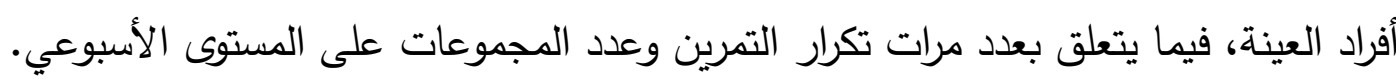

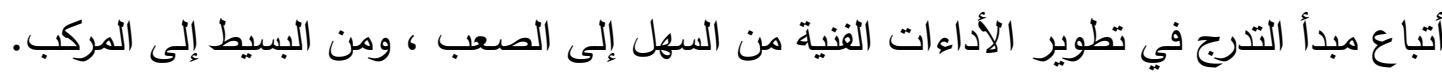

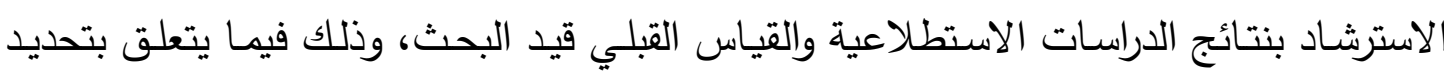
جرعة البداية وزمن الفترة التدربية. ه الاسترشاد باراء الخبراء والمتخصصين في تدريب كرة القدم في تحديد ابعاد محتوى البرنامج

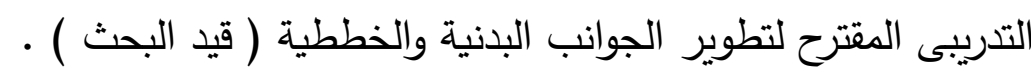

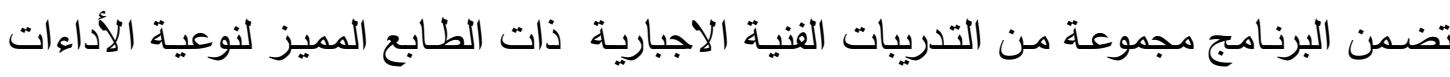

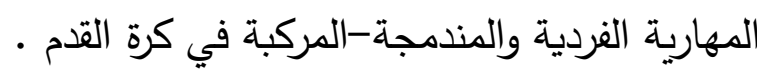
م مراعاة عوامل الأمن والسلامة على مدار فترة تتفيذ البرنامج.

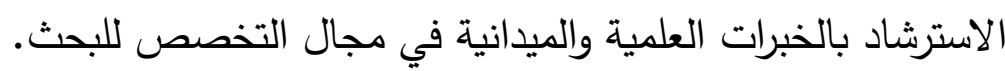


أسس وضع البرنامج:

انطلاقا من أهداف البحث وخصائص عينـة البحث ومن خـلال المستح المرجعي والاستفادة بآراء

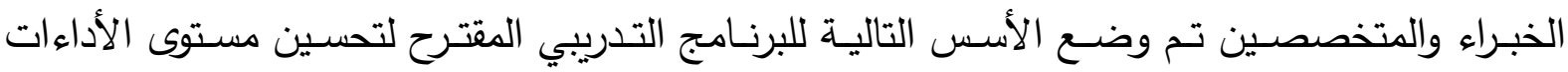
المهارية المنفردة والمندمجة (قيد البحث) وبما يتناسب مع أهداف البحث : قام الباحثان بتحديد خطوات تصميم البرنامج التدريبى المقترح على النحو التالى: تحديد نوع الفترة التدريبية المطلوب تخطيط المطلوب تخطيط محتويات برنامجها زمنياً. تحديد عدد أسابيع الفترة الزمنية. • تحديد عدد مرات التدريب الأسبوعية.

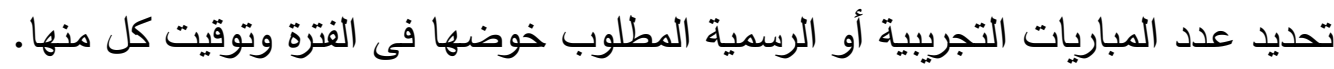
تحديد زمن كل وحدة تدريبية وتسكين المباريات التجريبية والراحة خلال أسابيع الفترة كلها. تحديد مجموعة أزمنة الإعداد خلال وحدات التدريب كل أسبوع والمباريات التجريبية. تحديد زمن التدريب الكلى لفترة الإعداد من خلال متوسط زمن التدريب الكلى للفترة. توزيع نسب محتوى الإعداد للفترة ككل. توزيع نسب محتوى الإعداد لكل أسبوع من أسابيع الفترة. تقسيم الأسابيع إلى مراحل وتحديد نسبة الإعداد فى كل منها. توزيع أزمنة محتوى الإعداد فى كل أسبوع داخل المرحلة طبقاً لنسبته.

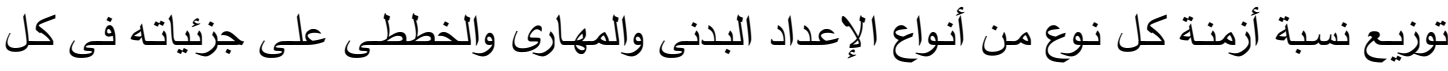
أسبوع. توزيع أزمنة كل نوع من أنواع الإعداد على جزئياته بعد التوصل إلى نسبة توزيع أزمنة كل من

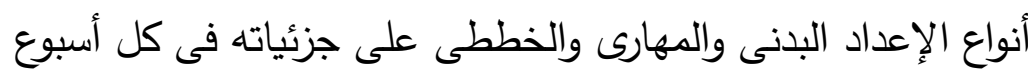

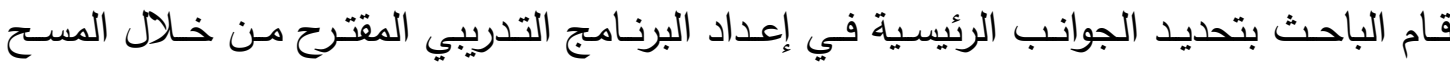

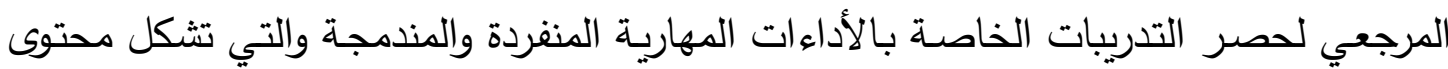
البرنامج التدريبي المقترح. تم ترتيب الوحدات التدريبية من السهل إلى الصعب ( الحجم - الثدة - الكثافة) لملائمتها للمرحلة السنية والمستوى الخططى للناشئين عينة البحث.

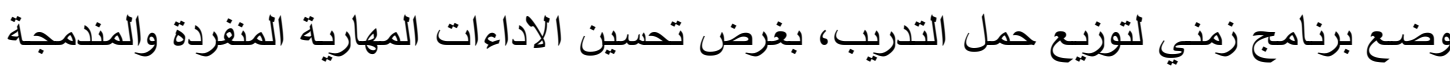


• التدرج في التمرينات من السهل إلي الصعب ومن البسيط إلي المركب ومن العام إلي الخاص،

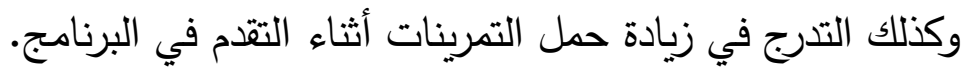

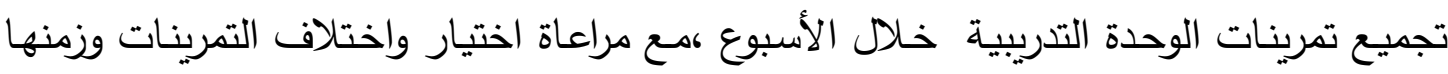
من وحدة تدريبية إلي وحدة تدريبية أخرى خلال الأسبوع وذلك لتسهيل وتثبيت أداء التمرينات علي عينة البحث من الناشئين. مراعاة الفروق الفردية للاعبين.

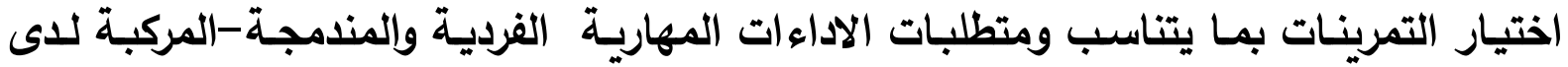
ناشئى كرة القدم قيد البحث: قام الباحثان بتحديد محتوى البرنامج التدريبى المقترح حيث اشتمل البرنامج على مجموعـه من التدريبات الفنية الاجبارية والتى تهدف الى تحسين المهارات المنفردة والمندمجة ( قيد البحث ) بإجمالي

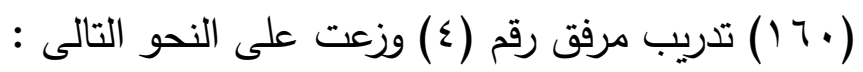
تدريبات فنية إجبارية فردية (V^) تدريب .

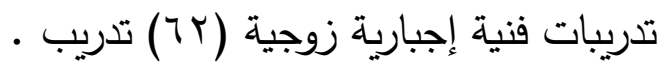

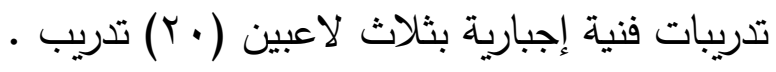

تحديد أولويات وواجبات التدربب: قام الباحث في البداية بتحديد أهداف البرنامج التدريبي المقترح ثم قام بتوزيع هذه الأهداف إلي

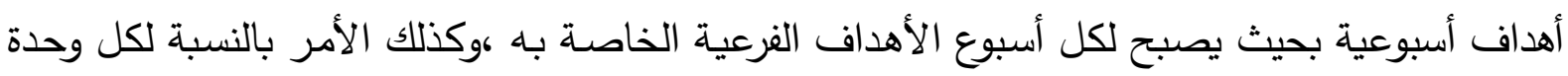

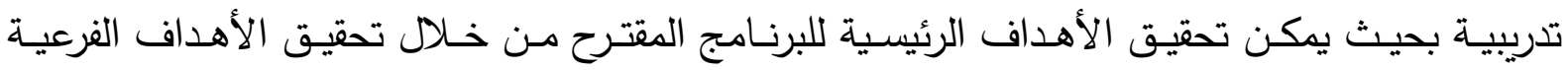

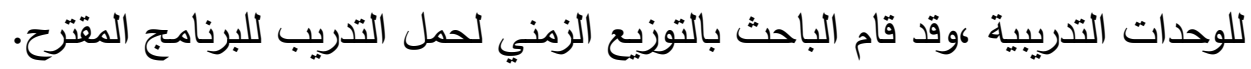

المرونة في تصميم البرنامج وتناسبه مع إمكانية التطبيق العملي :

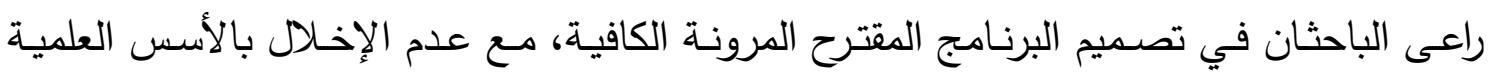

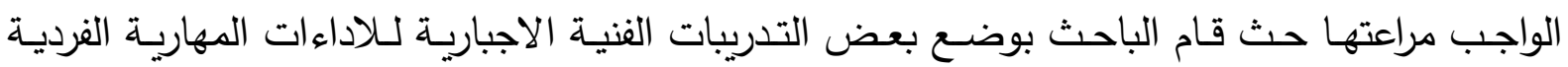
والمندمجة-المركبة قيد البحث حتى تتناسب مع خصائص عينة البحث مسترشداً في ذلك بما أسفرت عنه الدراسات الاستطلاعية. 
ملائمة البرنامج لعينة البحث:

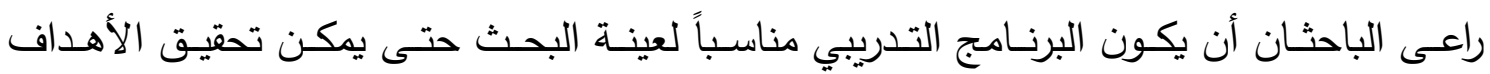

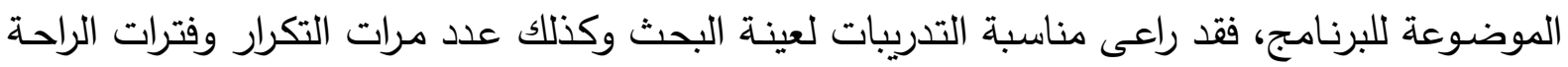
البينية بالإضافة إلي أسلوب التشويق من اجل تحقيق الأهداف الموضوعة للئلة للبرنامج المقترح.

تعديد مدة تطبيق البرنامج :

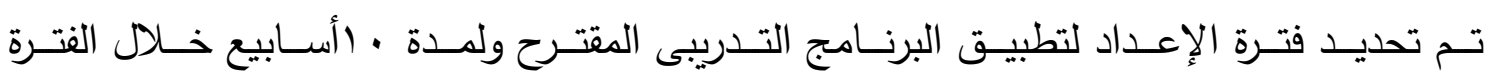

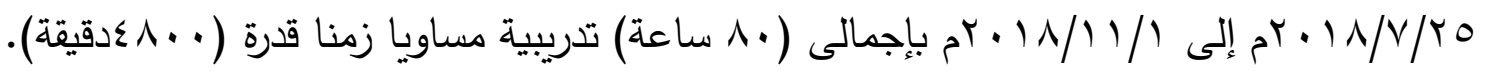
وقد تم تنفيذ البرنامج التدريبى خلال فترات (الاعداد العام - الاعداد الخاص - الاعداد للمباريات) وكان توزيعها كالاتى: ت تصني

تقسيم فترة الإعداد:

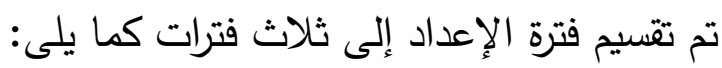
فترة الإعداد العام:

وهى تمثل الأسبوع الأول والثانى من البرنامج التدريبى بإجمالى زمن قدرة (• ـ ودقيقة ) بمتوسط

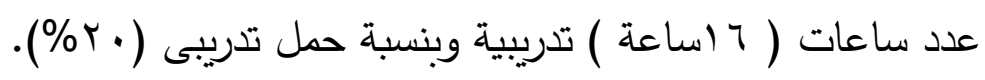
فترة الإعداد الخاص:

وهى تمثل الأسبوع الثالث والأسبوع الرابع والأسبوع الخامس بإجمالى زمن قدرة (•ـ ـ ادقيقة)

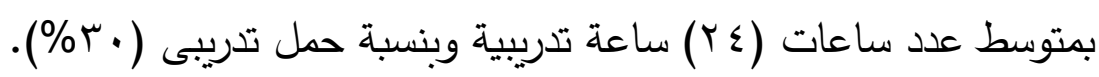
فترة الإعداد للمباريات:

وهى تمثل الأسبوع السادس والأسبوع السـابع والأسبوع الثامن الأسبوع التاسع والأسبوع العاشر

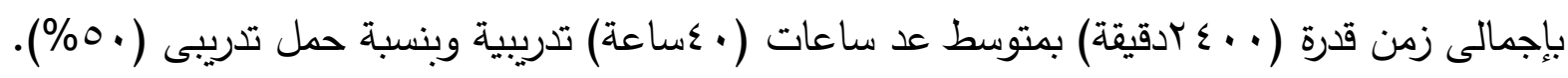
مكونات الوحدات التدريبية اليومية للجزء الرئيسى فى البرنامج التدرببى:

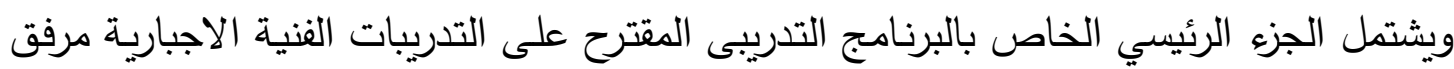

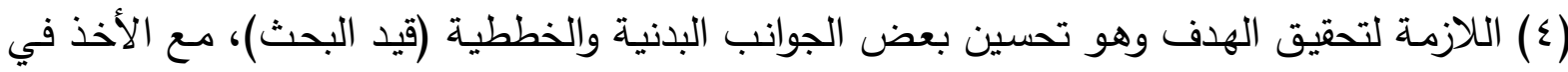

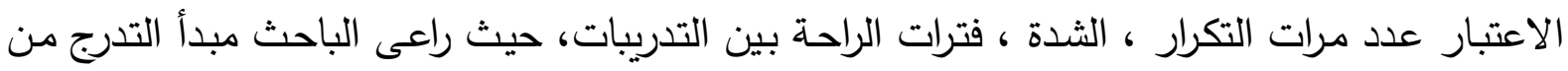

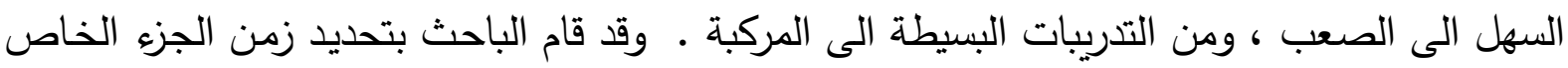

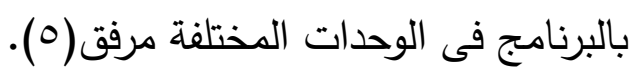


وقد مثلت فترة الجزء الخاص بالاعداد المهارى باستخدام التدريبات الفنية الاجبارية (قيد البحث)

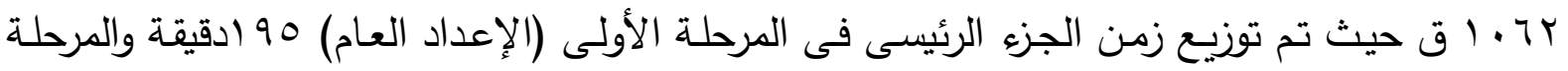

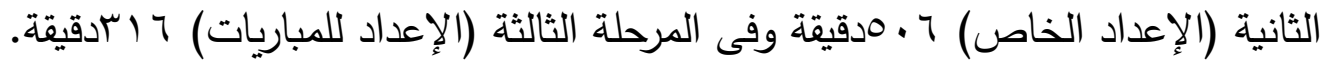

ثامناً: الدراسة الأساسية:

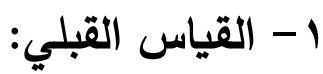

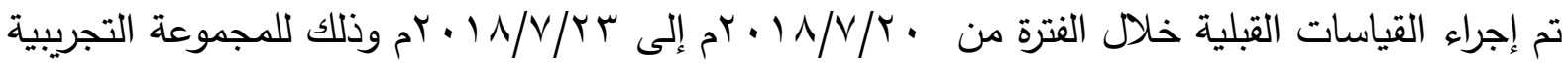

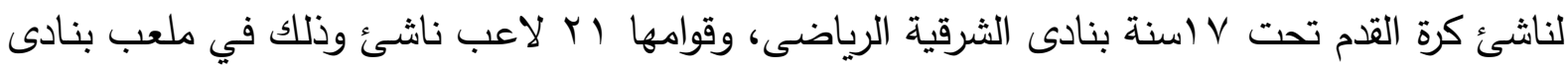

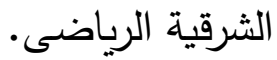

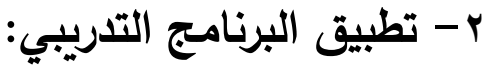

تم تتفيذ البرنامج التدريبي المقترح لمدة (· • () عشرة أسابيع من البرنامج التدريبي الرئيسي المقرر

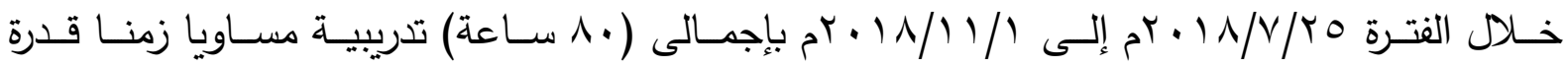

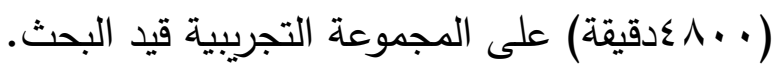

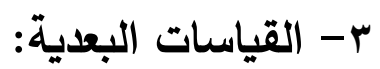

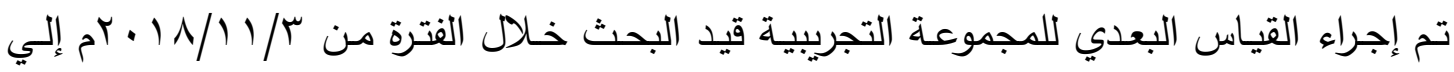

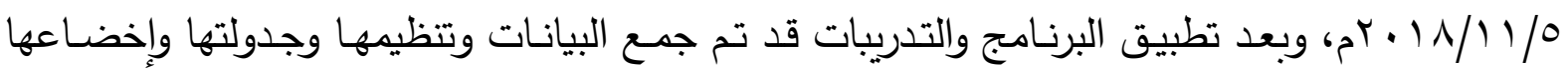
للمعالجة الإحصائية. تاسعا: المعالجات الإحصائية: إستخدم الباحثان المعالجات الإحصائية للبيانات بإستخدام ما يلي:

- -

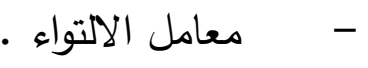
- معامل الارتباط (بيرسون) -

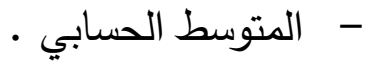

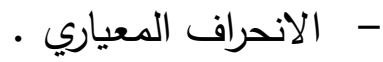
- 


\section{عرض ومناقشة النتائج:

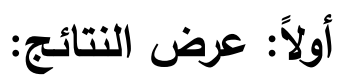

جدول (ء أ)

دلالة الفروق بين القياسين القبلي والبعدي

في تحسين بعض الجوانب البذنية قيد البحث البعائ

\begin{tabular}{|c|c|c|c|c|c|c|c|}
\hline \multirow{2}{*}{ قيمة (تحسة } & \multicolumn{2}{|c|}{ القياس البعدي } & \multicolumn{2}{|c|}{ القياس القبلي } & \multirow{2}{*}{ ولقياس } & \multirow{2}{*}{ المتغيرات } & \multirow[b]{2}{*}{ r } \\
\hline & $r \varepsilon^{ \pm}$ & س & $\varepsilon^{ \pm}$ & س & & & \\
\hline$r, q q$ & זד, & $r, \wedge \Lambda$ & $\cdot, r$. & $\{, 09$ & ثانية & سرعه انتقالية & 1 \\
\hline$r, V r$ & $1, \pi r$ & $r r, r \varepsilon$ & 1,14 & $r 0, . \theta$ & ثانية & تحمل السرعة & r \\
\hline$\varepsilon, r r$ & • & $r q, 1 r$ & $1, .7$ & $r q, r r$ & سم سم & قدرة عضلية & r \\
\hline $7, Y 1$ & $\cdot, \wedge 9$ & 0,11 & $1,1 \mathrm{~V}$ & $r, I V$ & سم & مرونة & $\varepsilon$ \\
\hline$\uparrow, \wedge q$ &., 17 & $\Lambda, \neg r$ & $\cdot, \varepsilon r$ & 9,00 & ثانية & رشاقة & 0 \\
\hline
\end{tabular}

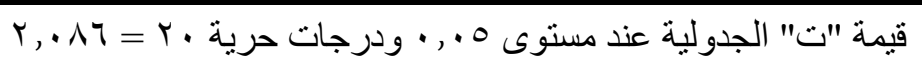

يتضح من جدول (ع ()) وجود فروق ذات دلالة إحصائية في الدتغيرات البدنية قيد البحث بين القياس القبلي

والقياس البعدي لصالح القياس البعدي.. 
جدول (10)

دلالة الفروق بين القياسين القبلي والبعدي

$r=\dot{0}$

في تحسين مستوى بعض الجوانب الخططية

\begin{tabular}{|c|c|c|c|c|c|c|c|c|}
\hline \multirow{2}{*}{ قيمة (تصوبة } & \multicolumn{2}{|c|}{ القياس البعدي } & \multicolumn{2}{|c|}{ القياس القبلي } & \multirow{2}{*}{ القياس } & \multirow[b]{2}{*}{ المتغيرات } & \multirow{2}{*}{ الخطوانبة } & \multirow[b]{2}{*}{ r } \\
\hline & $1 \varepsilon \pm$ & س & $1 \varepsilon \pm$ & س & & & & \\
\hline$* 7,7$. & $\cdot, \vee \vee q$ & $7, \ldots$ & $\cdot, \wedge 0$ & $r, q$. & درجة & العمق في الدفاع & & \\
\hline$* \varphi, \eta 1$ & $\cdot, V_{1}$ & $r, q$. & $\cdot, V \leqslant$ & 1,10 & درجة & التأخير في الدفاع & & 1 \\
\hline$* Y, Y)$ & $\cdot, 4$ & $0, .0$ & $\cdot, V Y$ & $r$ & درجة & الاتزان في الدفاع & & \\
\hline$* Y, 09$ & $\cdot, 0 T$ & $11, r q$ & $\cdot, 9 \varepsilon$ & Ir,TV & ثانية & الأداء الخططي الزوجي & & \\
\hline$* Y, 17$ & $\cdot, 91$ & $1, \varepsilon \Gamma$ & •, 94 & $1, .0$ & درجة & رقم (') & & \\
\hline$* \xi, Y V$ & $\cdot, \wedge 4$ & $q, \wedge \vee$ & • & $11, \cdot v$ & ثانية & الأداء الخططى الزوجي & & \\
\hline$* Y, q$. & $\cdot, \mathrm{Vq}$ & 1,74 & $\cdot, \Lambda \mu$ & $1, r \mu$ & درجة & رقم (ت) & & \\
\hline$* 4, \cdot 1$ & $\cdot$, Or & 11,01 & $\cdot, \wedge 1$ & $1 T, \varepsilon$ & ثانية & الأداء الخططي الزوجي & & \\
\hline$* r, Y I$ & $\cdot, \wedge 4$ & 1,90 & $\cdot, \wedge \vee$ & $1, \leqslant \wedge$ & درجة & رقم (r) & & \\
\hline$* \Psi, 9 \leq$ & $\cdot, \wedge 9$ & IY,Or & $\cdot, 97$ & $1 \leq, 91$ & ثانية & الأداء الخططى الزوجى & & \\
\hline$* Y, q$. & $\cdot, 94$ & 1,90 & •, 94 & $1,0 r$ & درجة & رقم (צ) & & $T$ \\
\hline$* \varepsilon, 0 \wedge$ & $\cdot, 71$ & $11, .9$ & $\cdot, 00$ & $I Y, V Y$ & ثانية & ال الأداء & & \\
\hline$* \Psi, Y I$ & $\cdot, \wedge 9$ & $1,9$. & $\cdot, \mathrm{V} \bullet$ & $1, \varepsilon r$ & درجة & الجماعي بنداته لاعبين & & \\
\hline$* Y, V_{0}$ & $\cdot, 9 \leqslant$ & 11,09 & $\cdot, 71$ & $1 r, .9$ & ثانية & الأداء الخططي & & \\
\hline$* r, \wedge r$ & $\cdot, \wedge$. & $r, \cdot \varepsilon$ & $\cdot v \leq$ & $1, \leqslant \wedge$ & درجة & رقبم (r) ربه لاعبين & & \\
\hline *Y,AI & $1, .0$ & $\mid r, \wedge \Lambda$ & • & $1 \leqslant,+7$ & ثانية & 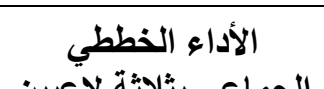 & & \\
\hline$* r, r q$ & $1, \leqslant 7$ & 1,14 & $\cdot, 91$ & 1,19 & درجة & 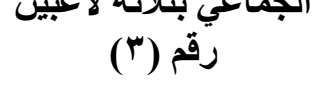 & & \\
\hline
\end{tabular}

يتضح من جدول (10) وجود فروق ذات دلالة إحصائية في المتغيرات الخططية قيد البحث بين القياس القبلي

والقياس البعدي لصالح القياس البعدي. 
جدول (17)

دلالة الفروق بين القياسين القبلي والبعدي

في تحسين مستوى بعض الجوانب الخططية

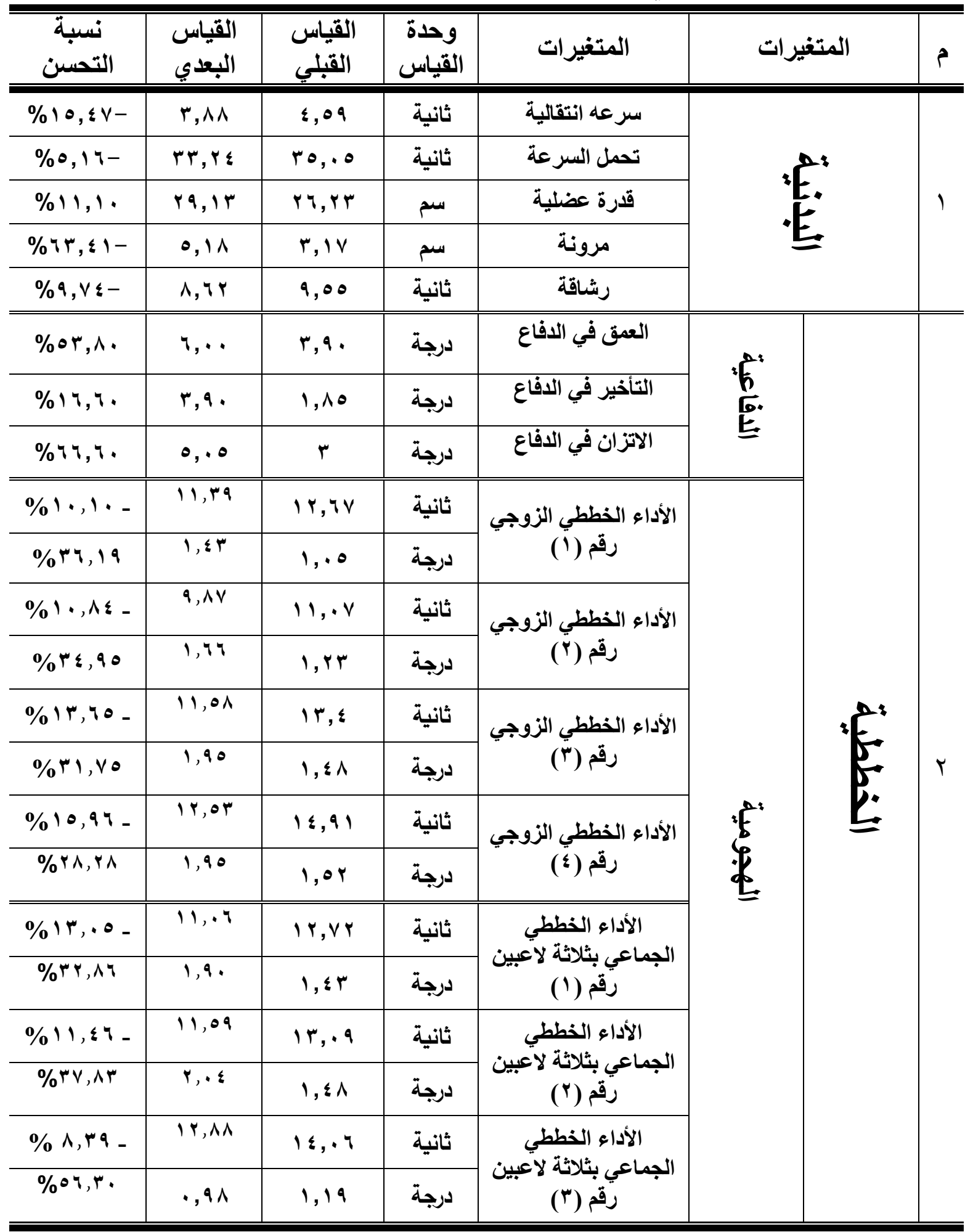


يتضح من جدول (7 (1) وجود نسب تحسن في تطوير أداء بعض الجوانب البدنية والخططية قيد البحث ، بين

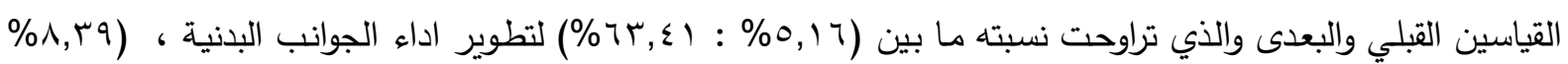

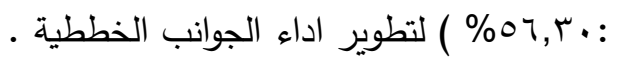

ثانياً: مناقشة النتائج: فى ضـوء نتائج التحليل الإحصـائى لبيانـات البحث والاعتمـاد على المراجـع العلميـة والدراسـات المرتبطة تم مناقشة النتائج وفقًا لفروض البحث كما يلى:

\section{مناقشة نتائج الفرض الأول:}

يتضـح من جدول (ع 1) وجود فروق دالة إحصـائياً بين القياس القبلي والبعدي لدى المجموعـة التجريبية لصـالح القياس البعدي فى المتغيرات البدنيـة، حيث بلغت قيم (ت) المحسوبة في متغيرات الجوانب البدنية (السرعة الانتقالية ، تحمل السرعة ، القدرة العضلية ، المرونـة ، الرشاقة) علي التوالي ( ) ( عندمستوى دلالتةإحصـائية (ه . . • ) ممايدل على وجود فروق دالـةإحصـائياً لصـالح القياسالبعدي لأفراد المجموعةالتجريبية.

ويرجح "الباحثـان" هذه الفروق الدالة إحصـائيا بين القياسين القبلي والبعدي للمجموعة التجريبية وهذا التحسن في اختبـارات متغيرات الجوانب البدنيـة والخططيـة قيد البحث إلي محتوي البرنـامج التدريبي المقترح والمطبق علي المجموعـة التجريبية الذي يحتوي علي تدريبات فنيـة اجباريـة والتي لها صـفة الخصوصسية المقصسودة في التدريبات والتي تم إعدادها وتقنينها علي أسس علمية ووفقاً لأراء الخبراء والأبحاث والدراسات المرتبطة في مجال علم التدريب الرياضي، حيث أنها كانت المتغير الوحيد الذي تم أضافته علي برنامج هذه المجموعة ، مما يشير إلي أهمية التدريبات الفنية الاجبارية المهارية في الارتقاء بالمستوي البدني والخططي.

وتشير هذه النتائج إلىى أن البرنـامج التدريبي باستخدام التدرببات الفنيـة الاجباريـة التى تتشـابه وطبيعة الأداء المهارى خلال المباراة قد أدى إلى تحسن بعض متغيرات الاداء البدني قيد البحث ، وذلك حيث أن استخدام برامج تدريبية ذات تخطيط جيد وعنايـة منظمـة، تؤدى إلى تتمية وتحسين الجوانب لبـي البدنيـة المختلفة ، وأن البرامج المقننـة والتي تراعى عند تصـيمها الأسس والمبادئ العلميـة والمنظمـة، وكذلك إتباع الأسـاليب العلمية في تقنين الأحمال من حيث (الثدة - الحجم - الكثافة)، مما أدى إلى تحسن وتطوير فى بعض الجوانب البدنية المختلفة ، كما راعى الباحث عدم الهبوط فى مستوى قوة 
وسرعة الأداء إضافة إلى مراعاة التدرج بالحمل التدريبى ومراعاة الفروق الفردية بين اللاعبين والمرونة فى التى

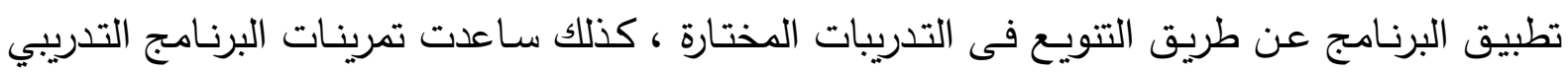

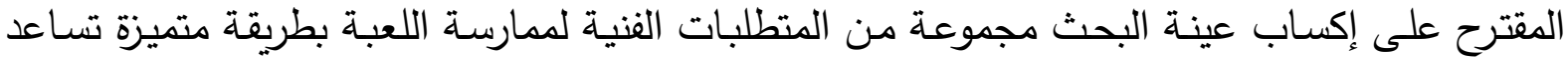

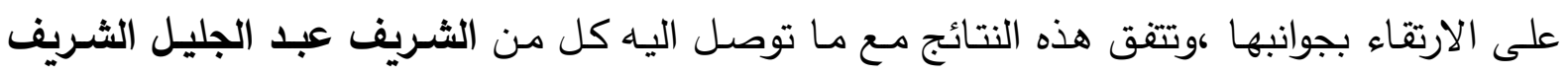

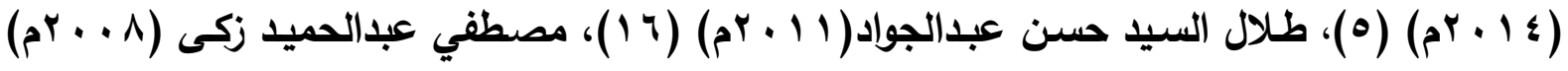

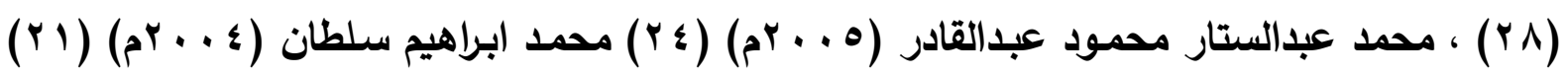

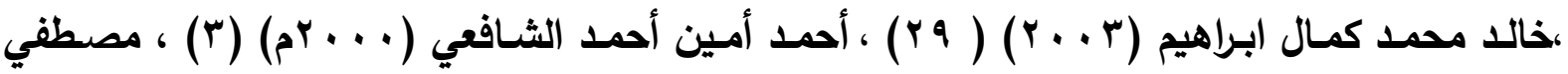

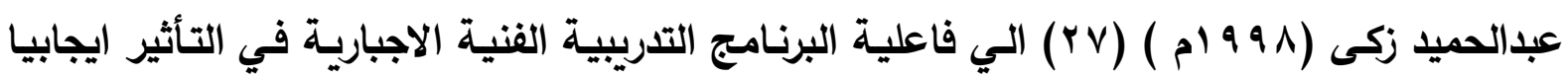
علي المتغيرات البدنية.

يشير عمـرو أبـو المجد ( •99 19م) بأن التخطيط الحديث في تدريب كرة القدم يلعب دوراً

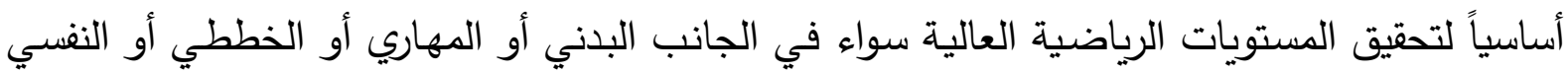

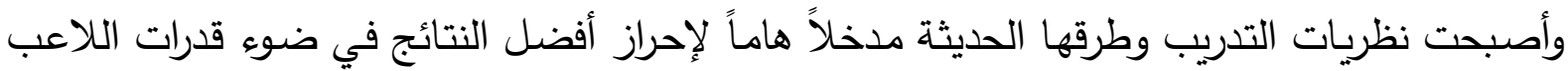
وإمكانياته. (19 (19)

ويذكر " عصام عبد الخالق" (0 . . rم) أن النواحى البدنية والمهارية والنفسية قد حظت باهتمام

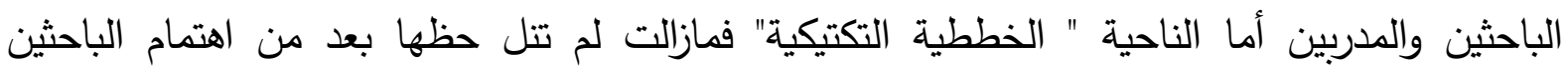
والمدربين ومازال هناك الكثير من الجوانب الخططية التى يجب أن يضعها المدربين نصب أعينهم أثناء

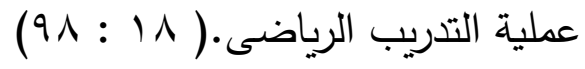

و يذكر حنفي محمود مختار (·99 ام) إلى أنه يجب علي المدرب أن يضع في اعتباره أن

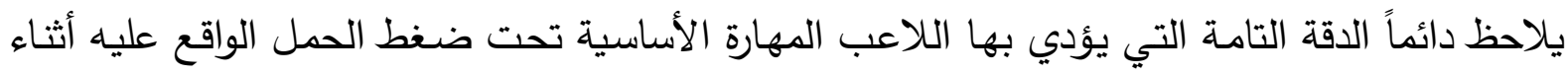

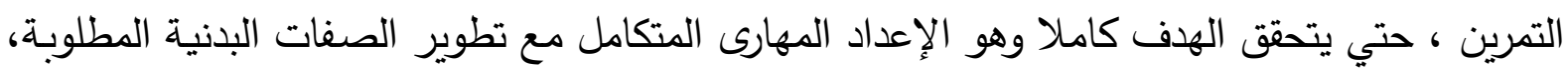
كما أن استخدام التمرينات المندمجة - المركبة يعمل علي تتمية الصفات البدنية للاعب.

$(11061 Y 0: 14)$

ويؤكد كل من حنفي محمود مختار ومفتى إبراهيم (919 ام) إلى أن كل مهارة أساسية في كرة

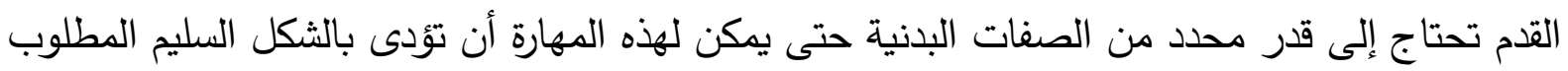

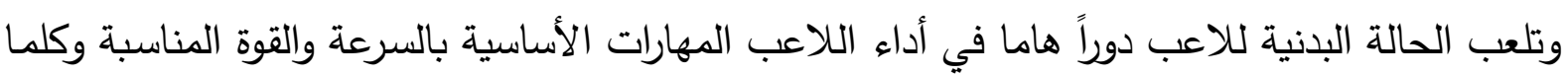

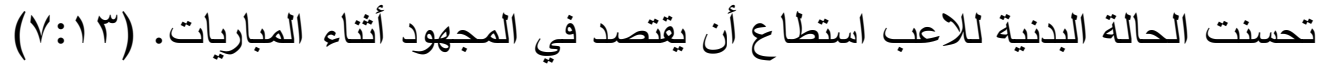


ويضيف عجمي محمد عجمي (990 190) نقلاً حنفي محمود مختار (ب99 ام) عن أن واجبات التدريب الحديث إتقان وتثبيت المهارات الأساسية بنفس السرعة لأدائها أئناء المباريات وتحت ضغط مدافع إيجابي حتى يتعود اللاعبون سرعة الأداء والحركة تحت ضغط ظروف اللعب المختلفة. ( V: V)

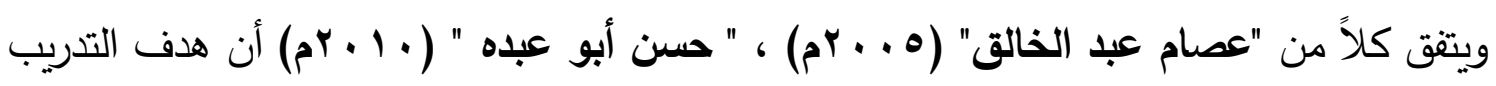
فى كرة القدم هو الإعداد المتكامل للاعب بدنياً ومهارياً وخططياً وفكرياً ونفسياً لتحقيق أعلى مستوى من إن الأداء المتكامل ويعتبر العمل الخططى فى كرة القدم الحديثة هو ذلك العمل التكتيكى الذى يحتوى الإى عناصر التكتيك الفردى والجماعى بهدف تنفيذ التحركات الهادفة والاقتصادية التى تقوم بها مجموعة من

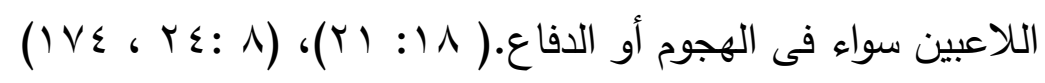

وبذلك يتحقق الفرض الأول للبحث والذى ينص على:" توجد فروق دالة إحصائيا بين القياس القبلي والقياس البعدي للمجموعة التجربيية لصـالح القياس البعدي في تطوير أداء بعض الجوانب البدنية لناشئي كرة القدم تحت 1 ا سنة.". مناقشة نتائج الفرض الثاني:

أظهـرت نتائج جدول (0 1 ) وجـود فروق دالـة إحصـائياً بـين القيـاس القبلي والبعدي لـى المجموعـة التجريبية لصـالح القياس البعدي فى المتغيرات البدنيـة، يث بلغت قيم (ت) المحسوبة في متغيرات الجوانب الخططية الدفاعية (العمق في الدفاع ، التأخير في الدفاع ، الاتزان في الدفاع)علي التوالي

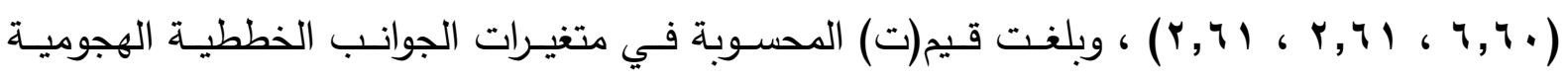
(زوجي (، زوجي r، زوجي r، زوجي ؛، جماعي بثلاث لاعبين I ، جماعي بثلاث لاعبين r ، جماعي

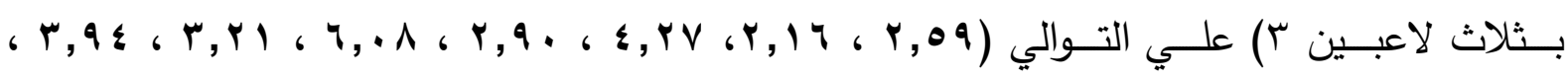
• .

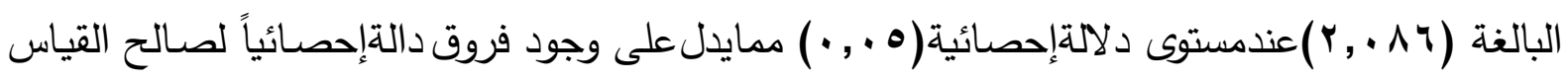
البعدي لأفراد المجموعةالتجريبية.

وتثير هذه النتائج إلى فاعلية البرنامج التدريبى المقترح والتى تم تصميمه باستخدام التدريبات

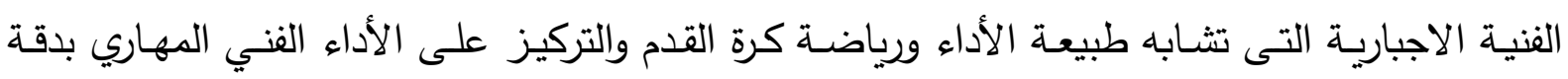
ومحاولة تطوير بعض الأداءات الخططية عن طريق التدريبات المقننة والمخصصة لناشئ كرة القدم. 
ويعزى الباحثان ذلك التأثير إلى البرنـامج التدريبى المقترح والموضـوع وفق للأسس العلميـة

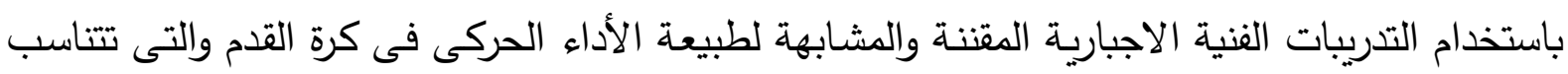

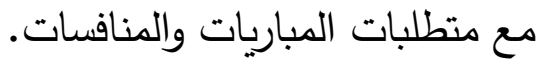

وهذا مـا يؤكد علي أن البرامج التدريبية لها دور هام في مجالات تأسيس النشه حيث أنها

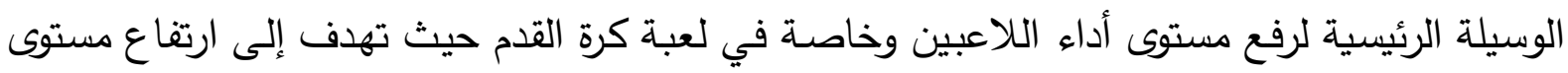

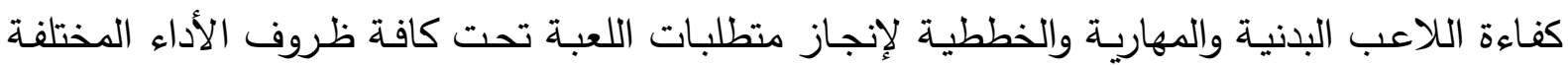
والمتعددة (19: (19)

وتتقق هذه النتائج مع ما توصل الية كل الثريف عبد الجليل الثريف (ع ا •rم) (0)، طلال

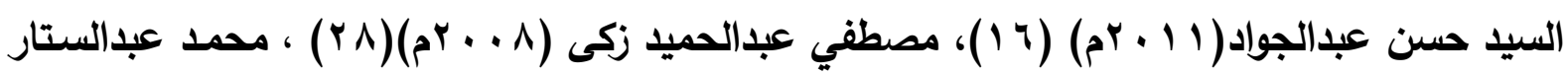

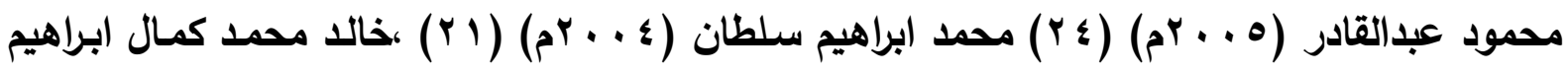

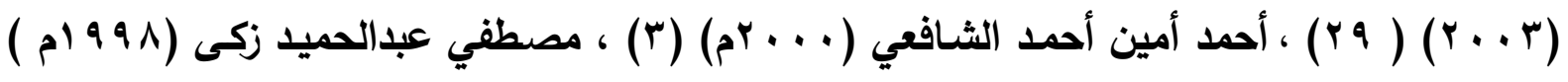

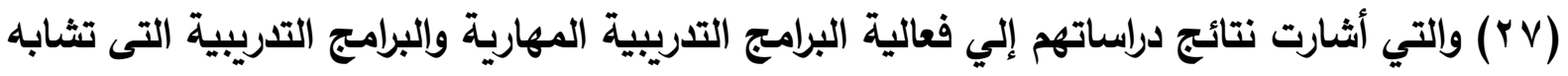

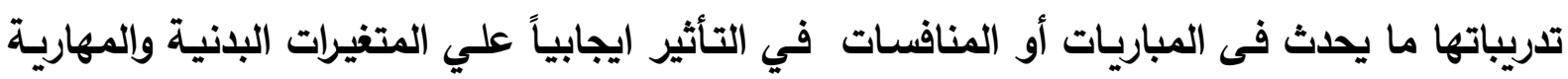

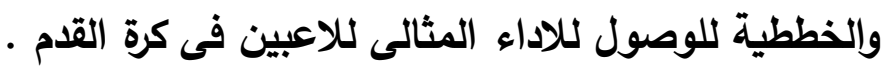

ويؤكد كل من حنفي محمود مختار ومفتى إبراهيم (919 ا9م) إلى أن كل مهارة أساسية في كرة

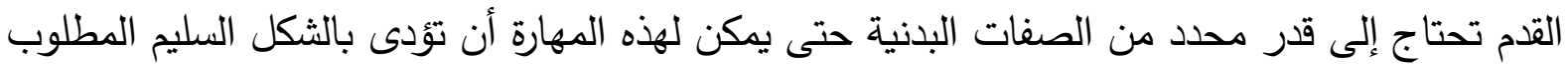

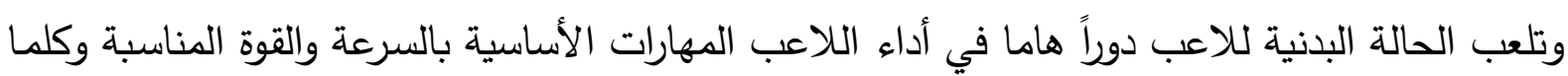

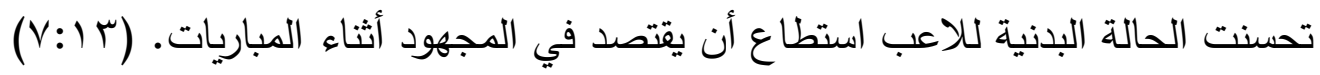

كما يؤكد منير جرجس إبراهيم (.99 (9) أن التدريب على المهارات الحركية يعتبر من أهم أركان العملية التدريبية وأكثرها حساسية ، فالتدريبات المهارية تأخذ الوقت الأطول على مدار التهار فترات التهات التدريب ،

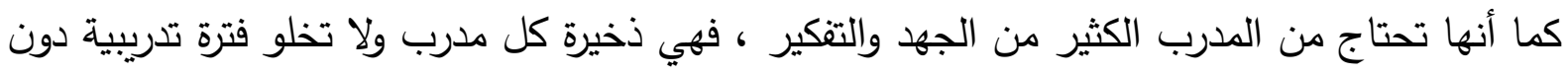

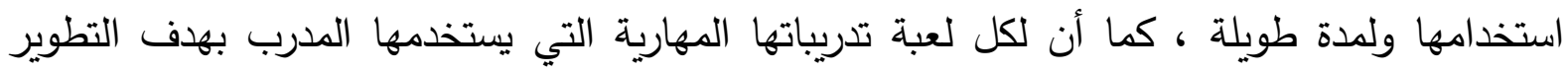

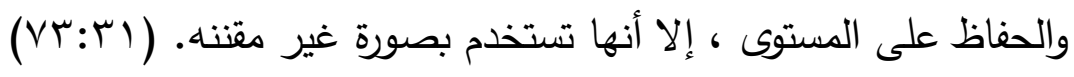

ويؤكد مفتى إبراهيم (919 19) على أن نجاح الأداء الحركي للاعب خلال المباراة يتوقف على درجة

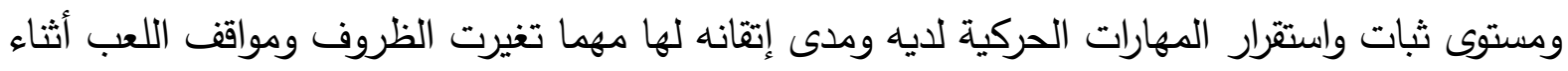
المباراة. (9:9:9 (19) 
ويؤكد خالد سعيد النبي إبراهيم (99V ام) على أن تدريب الناشئ على أشكال متتوعة من الأداء الحركي بما يشابه متطلبات المباراة يتيح له اختيار أفضلها وفق مواقف اللعب الفعلية وتئيد من قدربته

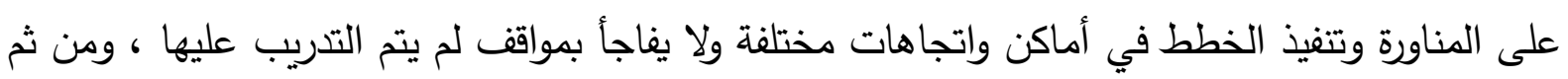

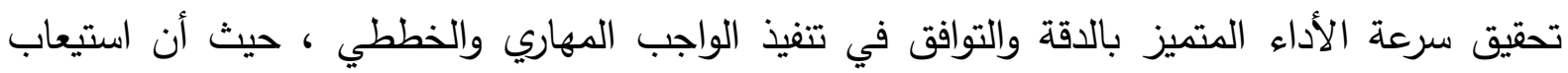

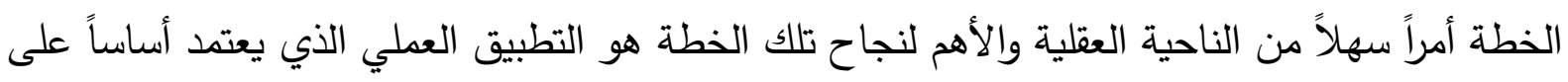

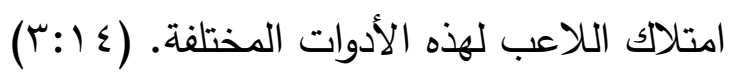

ويؤكد حنفي محمود مختار ( • 199 م) أن عملية تخطيط التدريب فى كرة القدم لها متطلبات

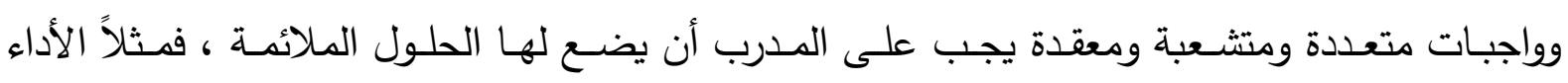

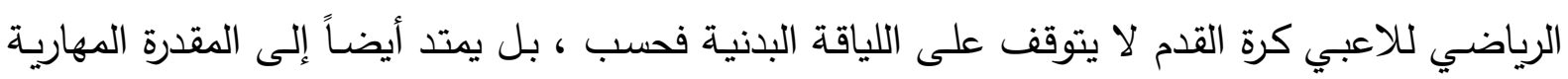

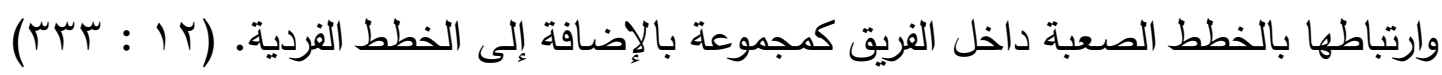
ويشير إبراهيم مجدي أحمد صالح (019 (م) انه من الملاحظ أن مستوى الأداء في كرة القدم

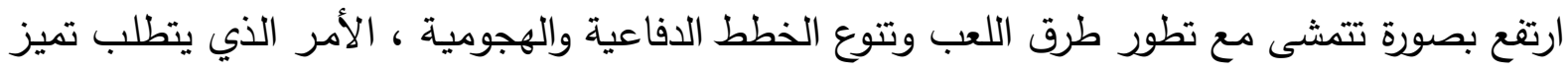
لاعب كرة القدم بأعلى مستوى من الأداء خلال المباريات ، وعليه فإنه يجب إعداد اللعاد اللاعب إعداداً فنياً

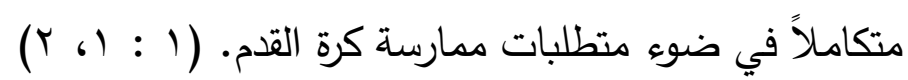
وبذلك يتحقق الفرض الثاني للبحث والذى ينص على:" توجد فروق دالة إحصائيا بين القياس

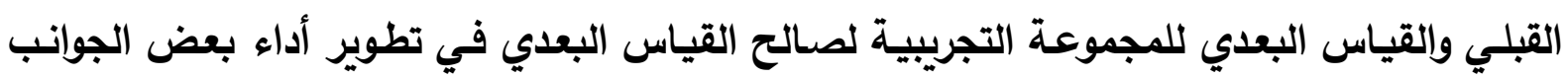
الخططية لناشئي كرة القدم تحت 1 1 سنة.".

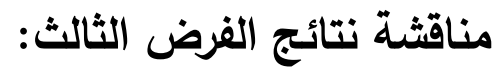

أظهرت نتائج جدول (7 (1) نسب تحسن بين القياسين القبلي والبعدي في متغيرات الجوانب

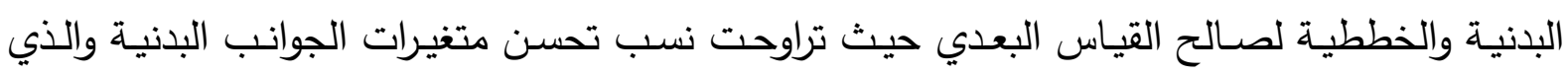

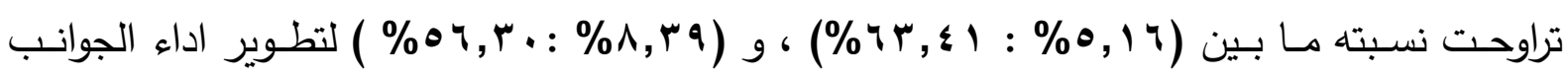
الخططية ، وبذلك تكون نسب التحسن المئوية لنتائج القياس المشار اليها لصالح القياس البعدي. وتثـير هذه النتائج إلى أن البرنـامج التدريبي باستخدام التدريبات الفنيـة الاجباريـة التى تتثـابه

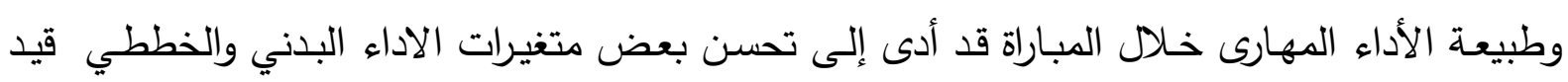

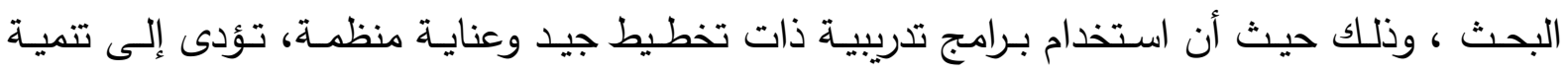

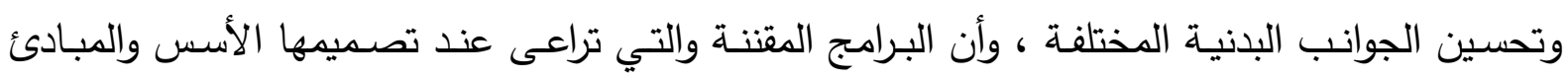


العلمية والمنظمة، ، مما أدى إلى تحسن وتطوير فى بعض الجوانب البدنية والجوانب الخططية المختلفة

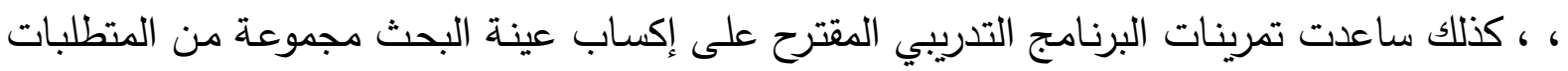

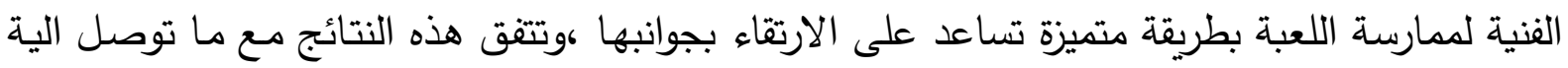

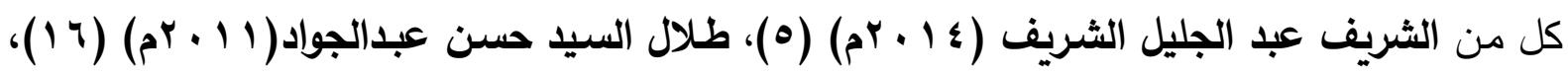

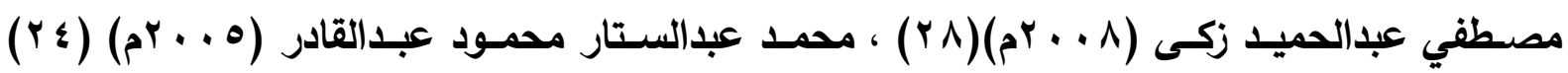

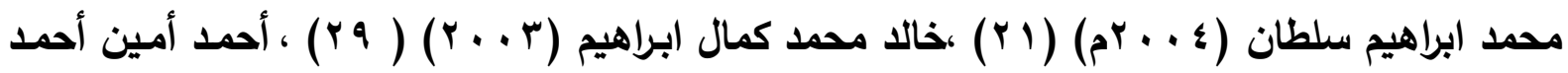

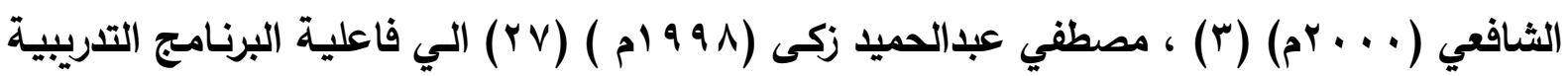

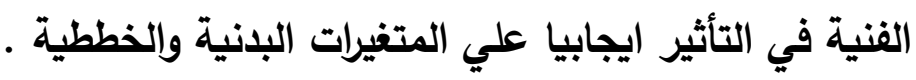
ويعزى الباحثان ذلك التأثير إلى البرنـامج التدريبى المقترح والموضـوع وفق للأسس العلميـة

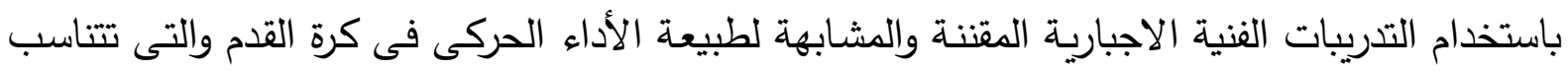

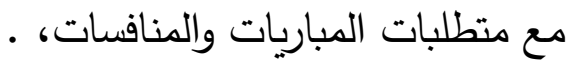

وهذا مـا يؤكد علي أن البرامج التدريبية لها دور هام في مجالات تأسيس النشء حيث أنها

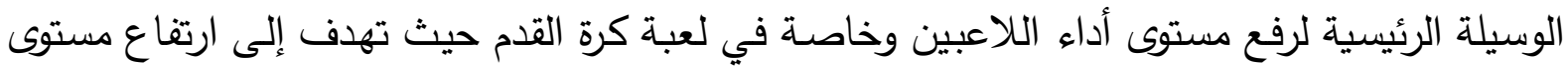

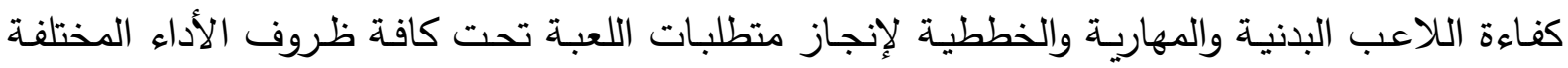
والمتعددة (19:1 (19)

Ken Goldman ويذكر إبراهيم محمد جمال الين (799 19 م) نقلاً عن كين جولامان وآخرون others

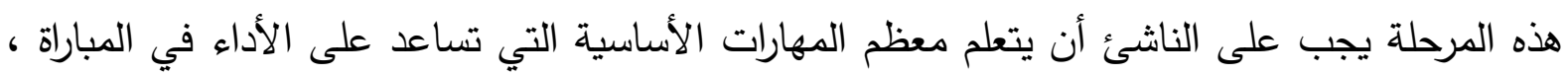

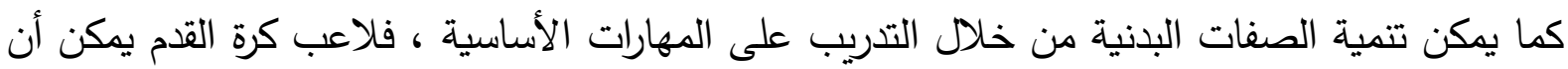

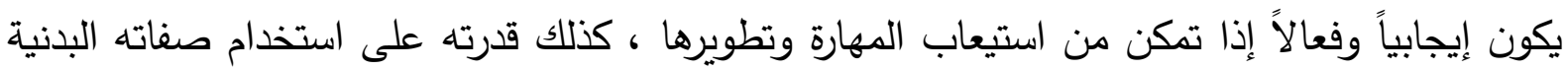

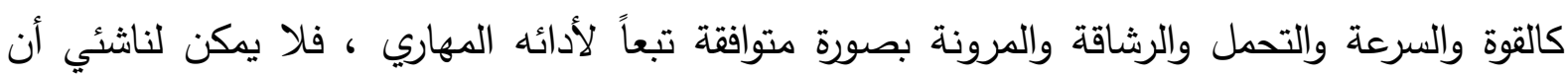
يكون ذا قدرة على أداء المهارات فى كرة القدم إذا لم يستطيع تقدير القوة والسرعة اللازمة لأدائها. $(\varepsilon: r)$

ويؤكد حنفي محمود مختار (• 199 م) أن عملية تخطيط التدريب فى كرة القدم لها متطلبات وواجبات متعددة ومتثـعبة ومعقدة يجب على المدرب أن يضـع لها الحلـول الملائمسة ، فمثلاً الأداء 
الرياضي للاعبي كرة القدم لا يتوقف على اللياقة البدنية فحسب ، بل يمتد أيضـاً إلى المقدرة المهاريـة

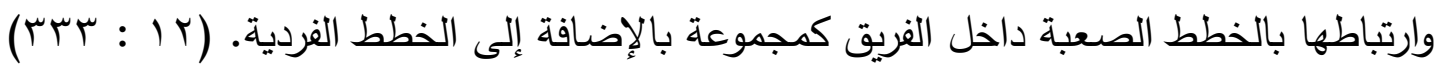

ويرى كل من حنفي محمود مختار (•191/م) ، محمود أبو العينين ومفتى إبراهيم (919 ام) أن

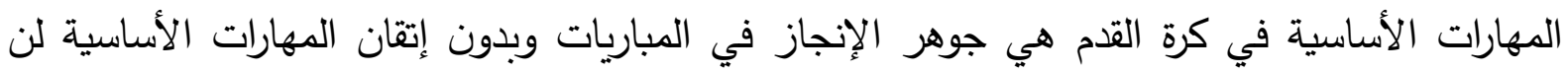

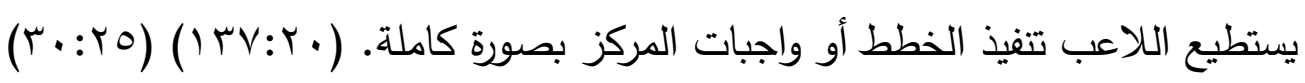

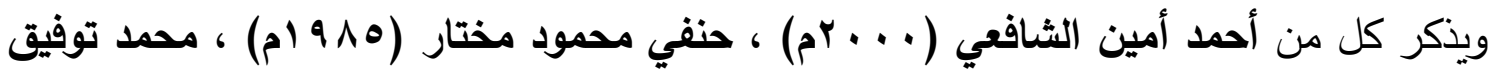

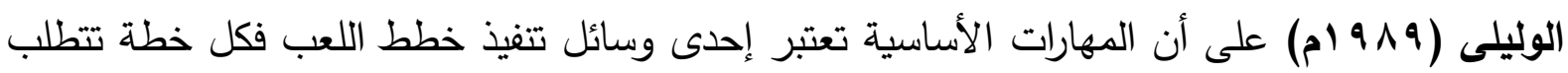
إتقان مهارة أساسية أو أكثر لتتفيذها ، لذلك يبني الجانب التكتيكي علي مدى قدرة اللاعبين على أداء

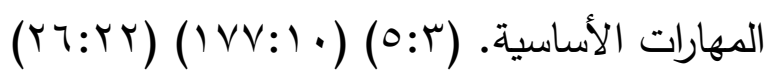

وهذا ما يؤكده كلاً من "عصام عبد الخالق" (ه . . r م) ، " حسن أبو عبده " ( • ب rم) أن هدف

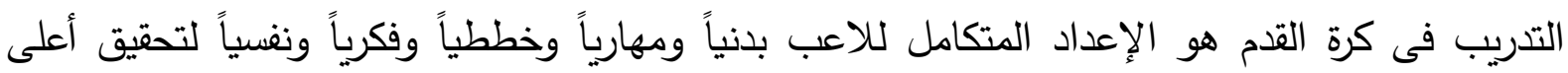
مستوى من الأداء المتكامل ويعتبر العمل الخططى فى كرة القدم الحديثة هو ذللك العمل التكتيكى الذى ولى ونى يحتوى عناصر التكتيك الفردى والجماعى بهدف تتفيذ التحركات الهادفة والاقتصادية التى تقوم بها

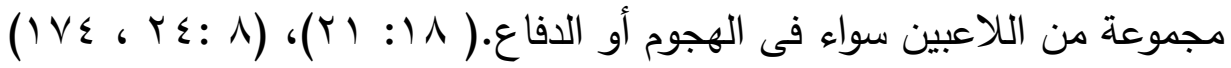
وبذلك يتحقق الفرض الثالث للبحث والذى ينصعلى:" توجد فروق فى نسب التحسن بين

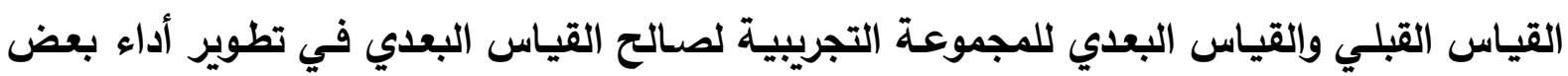
الجوانب البذنية والخططية لناشئي كرة القدم تحت 1 البنة سنة.".

الإستنتاجات والتوصيات:

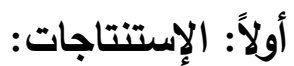

فى ضوء هدف البحث وفروضـه وفى حدود المنهج المستخدم وعينة البحث والأجهزة والأدوات

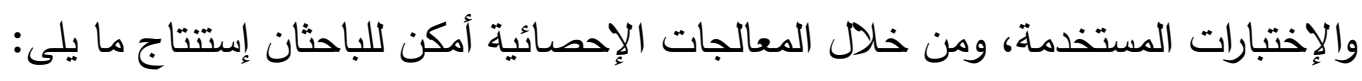
1- البرنامج التدريبى المقترح قد أثر تأثيراً إيجابياً فى تطوير أداء بعض الجوانب البدنية للناشئين تحت 1 | سنة. ץ- البرنامج التدريبى المقترح قد أثر تأثيراً إيجابياً فى تحسين بعض الجوانب الخططية الدفاعية لناشئى كرة القدم عينة البحث تحت 1/ اسنة. 
ب- البرنامج التدربیى المقترح قد أثر تأثيراً إيجابياً فى تحسين بعض الجوانب الخططية الهجومية لناشئى كرة القدم عينة البحث تحت 1 ا سنة. ع - ادى استخدام البرنامج التدريبي المقترح الى وجود فروق فى نسب التحسن القياسين القبلي والبعدي فى مستوى تطوير متغيرات الجوانب البدنية ومتغيرات الجوانب الخططية الدفاعية والهجومية . ثانياً: التوصيـات: إنطلاقاً مما أسفرت عنه الدراسة من إستتتاجات يوصي الباحثان بما يلي: ه- تطبيق برنامج التدريبات الفنية الاجباريـة المقترح لتطوير بعض الجوانب البدنية والخططية لناشئي كرة القدم علي المراحل السنية المختلفة. ج- الاستعانة بالبرنامج التدربيى المقترح - قيد البحث - عند التخطيط للتدريب الرباضى واسترشاد المدربين باه ومحاولة تطبيقه على لاعبيهم. V- ضرورة اهتمام المدربين بنوعية المهارات ووضعها فى تدريبات متدرجة الصعوبة من حيث التركيب بما يجعلها أكثر تثويقاً وتثابهاً لما يحدث فى المباريات. 1- الاهتمام بتقنين الاحمال التدريبية الخاصة بالتدريب علي المهارات الاساسية بنوعيها خلال فترة الاعداد وادراجها كمكون رئيسي خلال فترة المنافسات كتمهيد للواجب الخططي في الحصة التدريبية. 9- ضـرورة الاهتمام بتطوير السمات الارادية والنفسية والخلقية وكذلك تطوير القدرات العقلية للناشسين ، وتتمية الادراك الحس - حركي لما يتقارب مع مستوي الأداء خلال المنافسات. • - الاسترشاد بالأسس العلمية فى بناء وتصميم البرامج التدريبية الخاصة بمستوى ناشئ كرة القدم ا - محاولة استخدام طرق وأساليب التدريب المختلفة المناسبة للارتقاء بنواحي الأداء البدني والخططي لمراحل الناشئين المختلفة فى كرة القدم. ז ا - ضرورة إجراء بحوث مشابهه لتحديد مستحدثات التغيير في عالم كرة القدم بهدف الوصول الى أداء مثالى ومتكامل لجميع اللاعبين في المراحل السنية المختلفة. 
1-إبراهيم مجدى أحمد صالح : " دراسـة العلاقة بين مستوى الأداء المهارى وبعض الصفات

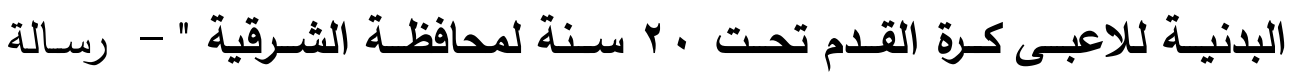

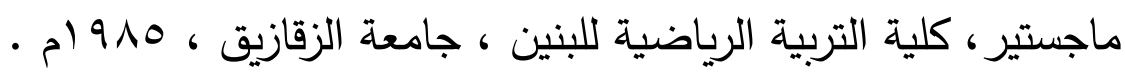

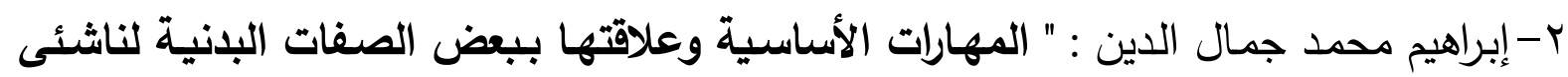

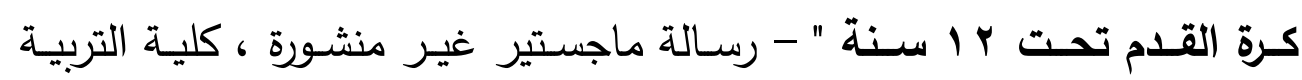
الرياضية للبنين ، جلمعة حلوان ، 1997 . 199

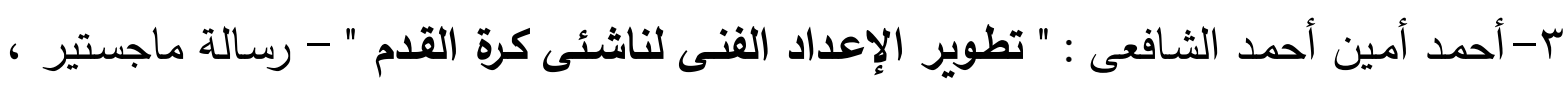

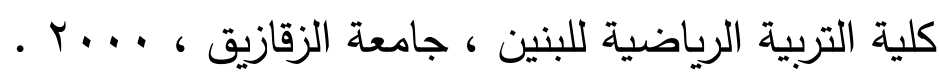
ع- أحمد محمد إبراهيم مصطفى: تقويم فاعلية بعض الاداءات الحركية المركبة - المندمجة -

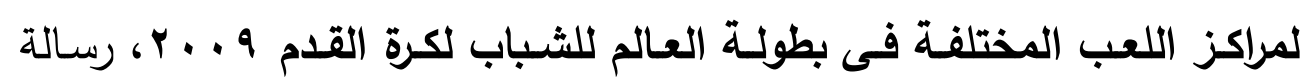

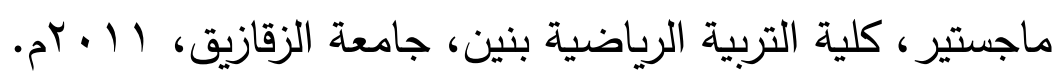

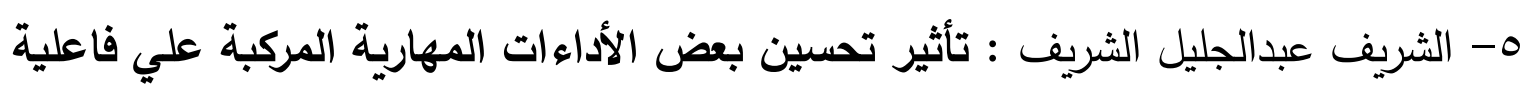

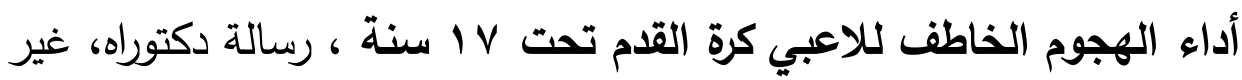
منشورة، كلية التربية الرياضية للبنين، جامعة الإسكندرية، ع أ بام.

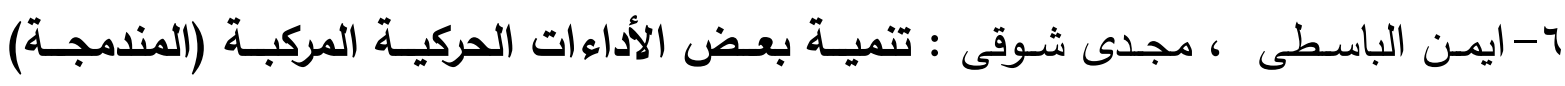

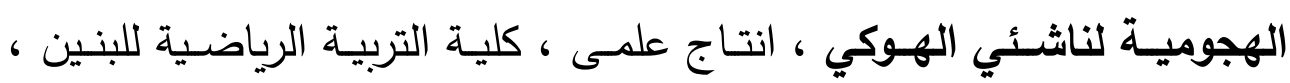

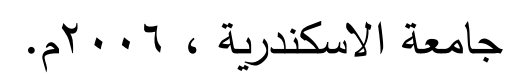

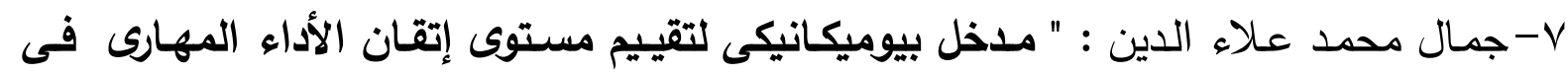

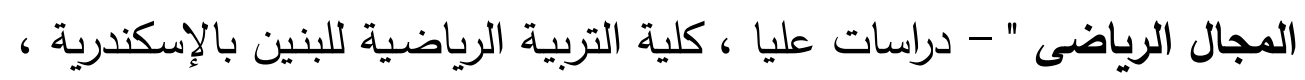

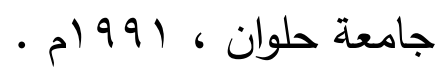
1- حسن السيد أبو عبده: الاتجاهات الحديثة فى تخطيط وتدريب كرة القدم، مكتبة الإثعاع الفنية، الطبعة العاشرة، الإسكندرية، • 1 • بم.

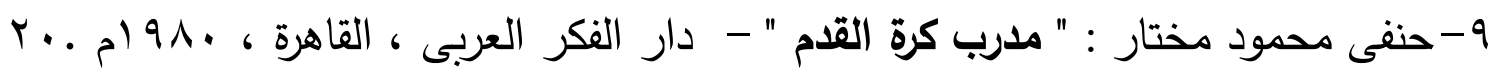


• 1- حنفى محمود مختار : " التـريب الحديث فى كرة القدم " - دار الفكر العربى ، القاهرة

$$
\text { - } 19106
$$

1 (- حنفى محمود مختار : " اسـس تخطيط بـرامج التـريب الرياضسى " - دار زهـران للنشـر والتوزيع ، القاهرة ، 911 ام.

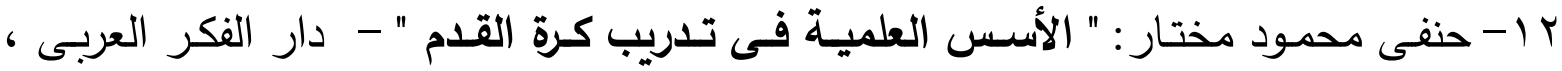

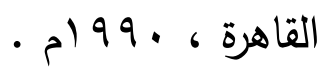

rا - حنفى محمود مختار ومفتى إبراهيم : " الإعداد البدنى فى كرة القدم " - دار زهران للنشر ، دهر

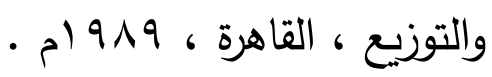

ع ا - خالد سعيد النبى إبراهيم : " تنمية سرعة ودقة الأداء الحركى بالكرة لدى ناشئى كرة القدم"

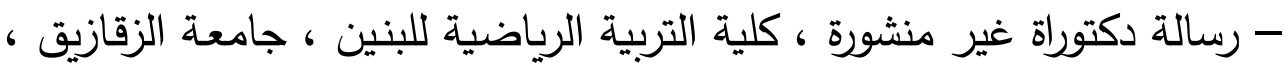

$$
\text { - 3) } 99 \mathrm{~V}
$$

0 ا - خالد محمد كمـال ابراهيم : تطوير بعض جوانب الأداء المهارى وعلاقتـه ببعض الجمل

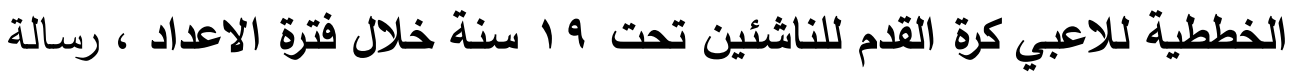

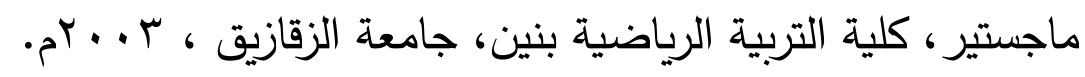

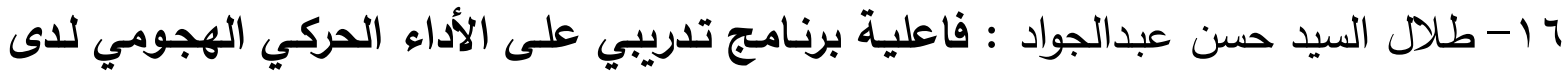

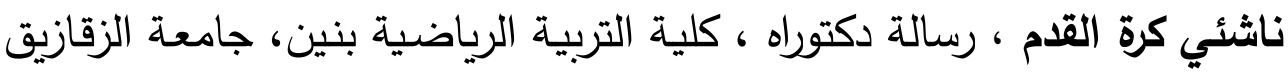

$$
\text { . }
$$

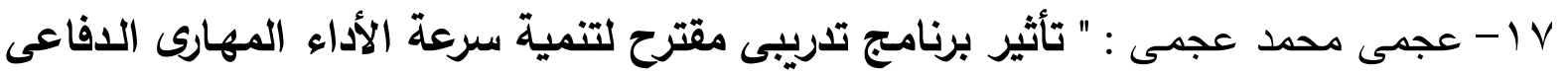

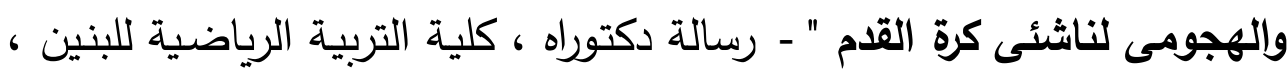

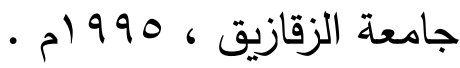
11 - عصام عبد الخالق : التدربب الرياضى (نظريات وتطبيقات) ، الطبعة الثانية عشر ، منشأة

$$
\text { المعارف، الإسكندرية ، } 0 \text {. . بام. }
$$

19- عمرو أبو المجد : تأثير برنامج تدريبي مقترح لفترة المنافسات علي المستوي البذني والاداء المهاري في كرة القدم، رسالة دكتوراه غير منشورة ، كلية التربية الرياضية

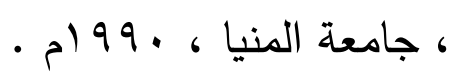

• ץ- لطفى محمد كمال : دراسة لبعض المتغيرات البيولوجية وعلاقتها بمستوى الإعداد الفنى ، 
للاعبى كرة القدم بالمملكة العربية السعودية - مجلة البحوث الرياضية ، المجلد

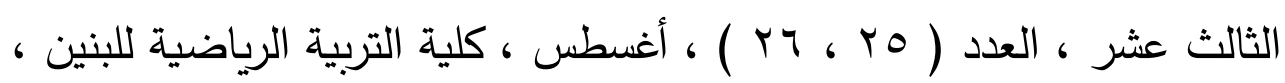

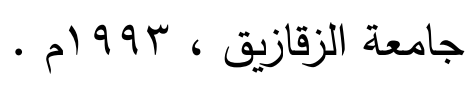

ا T- محمد ابراهيم سلطان : نسبة مسـاهمة المهارات الاساسية المركبة "المندمجة" على اداء

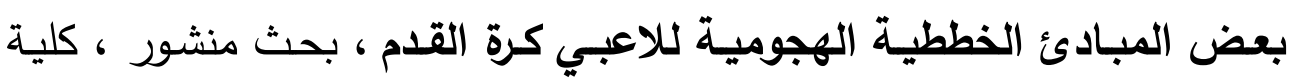

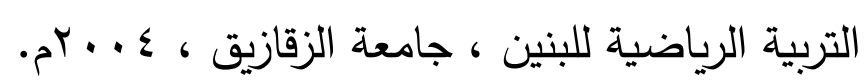

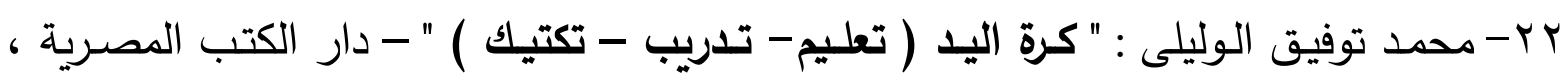

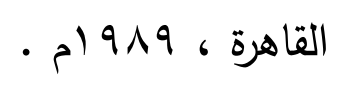

بr-محمد حسن علاوى : " علم التدريب الرياضس " - الطبعة العاشرة ، دار المعارف القاهرة ،

$$
\text { - م) } 917
$$

؟ ؟- محمد عبدالستار محمود عبدالقادر : تأثير تنمية الأداءات الحركية المركبة على بعض

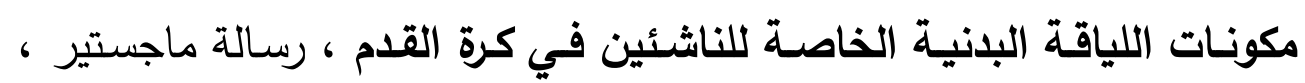

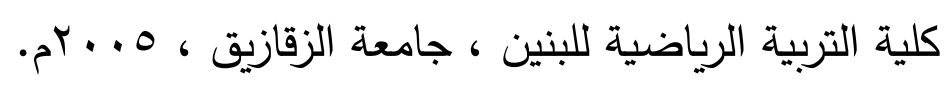

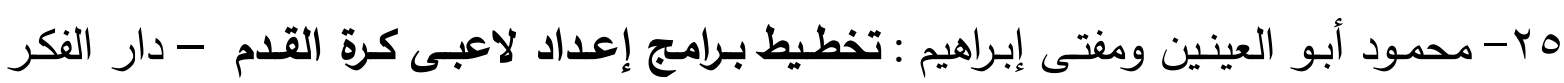

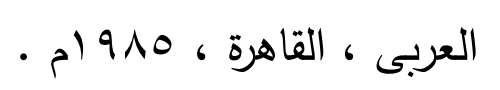

جץ- محمود محمد الحسيني محمد: " تأثير برنامج للتدريبات الفنية الإجبارية على تحسين

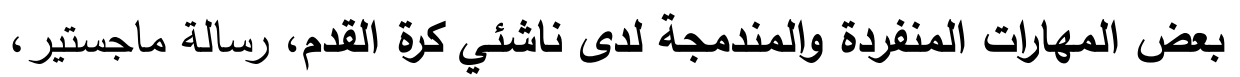

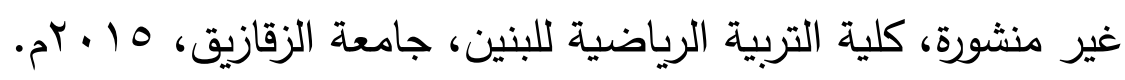

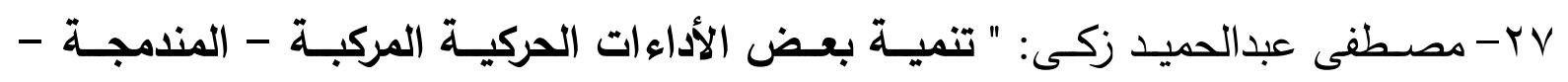

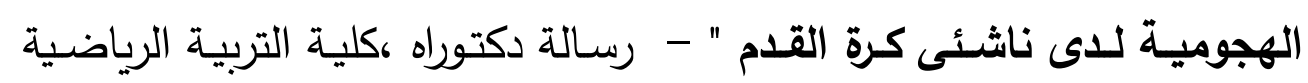

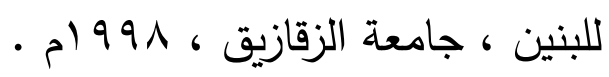

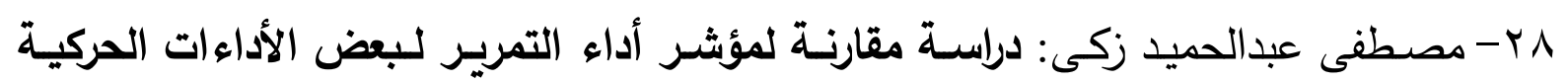

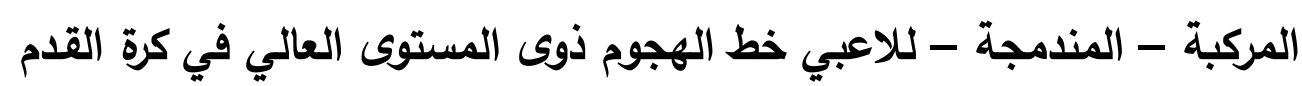

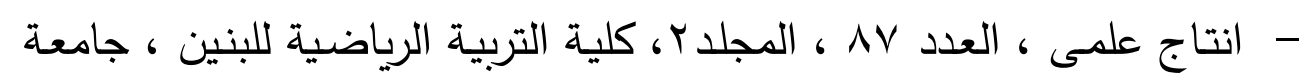
الزقازيق ، 1 . . بام. 
qץ- مفتى إبراهيم : مقارنـة بين تأثير استخدام الكرة فى كل محتويـات البرنامج التدريبى وبين

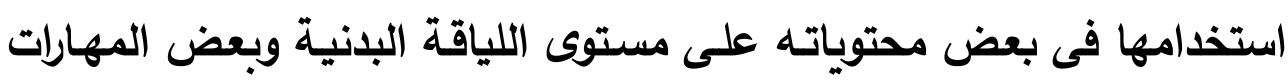

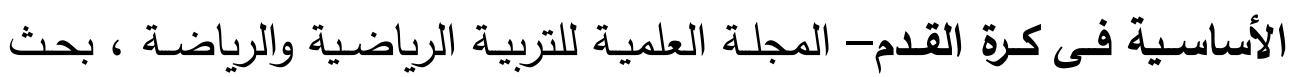

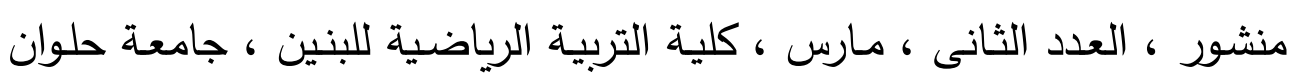

$$
\text { - م) } 9196
$$

• r- مفتى إبراهيم: الهجوم فى كرة القدم - دار الفكر العربى ، القاهرة ، .99 ام .

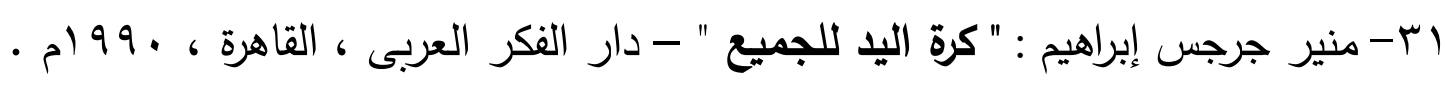

ثانياً : شبكة المعلومات الدولية:

32- https://www.almaany.com/ar/dict/ar-ar. 